\title{
LATE EOCENE OSTRACODA OF THE BLANCHE POINT FORMATION, SOUTH AUSTRALIA
}

\author{
Stefan MAJORAN
}

Department of Marine Geology, University of Göteborg, Geovetarcentrum, S-41381 Göteborg, Sweden

\begin{abstract}
Majoran, S. 1996. Late Eocene Ostracoda of the Blanche Point Formation, South Australia. Revista Española de
\end{abstract} Paleontología, 11 (1), 18-34. ISSN ()213-6937.

\begin{abstract}
The Blanche Point Formation (late Eocene) was deposited in the geographically restricted St Vincent Basin, South Australia. The Ostracoda of the Gull Rock and the Perkana Members (of this formation) are characterized by many cytherellids, krithiids, pontocypridids, bythocypridids and many sighted trachyleberidids. These taxa indicate outer shelf or epibathyal depths. Most specimens are represented by single valves, probably mainly as a consequence of the relatively slow sedimentation rate. The basal part of the Gull Rock Member yields a striking dominance of autochthonous cytherellids (synchronous with a peak in dominance of uvigerinid foraminifera) and might perhaps reflect intensification of oxygen minimum conditions. Six new species are proposed: Bairdoppilata willungaensis sp. nov., Trachyleberis maslinensis sp. nov., Trachyleberis reticulopustulosa sp. nov., Actinocythereis? onkaparingaensis sp. nov., Werribeeleberis? mediacosta sp. nov. and Bradleya mypongaensis sp. nov.
\end{abstract}

Keywords: Ostracoda, Eocene, Australia.

\section{RESUMEN}

La Formación Blanche Point (de edad Eoceno superior) fue depositada en la cuenca sedimentaria, restringida geográficamente de St Vincent, Australia del Sur. Los ostracodos de los Miembros Gull Rock y Perkana están caracterizados por la abundancia de representantes de las familias Cytherelledia, Krithiidae, Pontocyprididae, Bythocyprididae y de trachyleberididos con tubérculos oculares. Ambas asociaciones se interpretan como indicadores de profundidades epibatiales o plataformas externas. La mayor parte de los ostracodos están representados por valvas desarticuladas probablemente como un efecto de la velocidad de sedimentación relativemente lenta. Cytherellidos autóctonos dominan fuertemente la parte basal del Miembro Gull Rock, posiblemente como reflejo de una intensificación de las condiciones del oxígeno minimum. Seis especies nuevas son propuestas: Bairdoppilata willungaensis sp. nov., Trachyleberis maslinensis sp. nov., Trachyleberis reticulopustulosa sp. nov., Actinocythereis? onkaparingaensis sp. nov., Werribeeleberis? mediacosta sp. nov. y Bradleya mypongaensis sp. nov.

Palabras clave: Ostracodos, Eoceno, Australia.

\section{INTRODUCTION}

McKenzie et al. (1991, 1993) published the first comprehensive taxonomic works dealing with EoceneOligocene Ostracoda of South Australia and Victoria. Earlier contributions are more biostratigraphical and palaeoecological in scope, e.g. McKenzie (1974, 1979) and McKenzie \& Guha (1987). Palaeogene Ostracoda of New Zealand have been studied by Hornibrook (1952, 1953), Ayress (1990, 1993ab), Whatley et al. (1992) and Whatley \& Millson (1992).
The Ostracoda investigated here are late Eocene in age and derive from the type-section of the highly siliceous Blanche Point Formation which is exposed along the coastal outcrops of Maslin and Aldinga Beaches, near Port Willunga, South Australia (Fig. 1). These exposures are classical in Australian stratigraphy and well documented with respect to their foraminifera (Lindsay, 1967, 1985; McGowran \& Beecroft, 1986). McKenzie et al. (1991) described ostracod species from the Gull Rock Member of this formation. The present study is restricted to the Gull Rock and the Perkana 


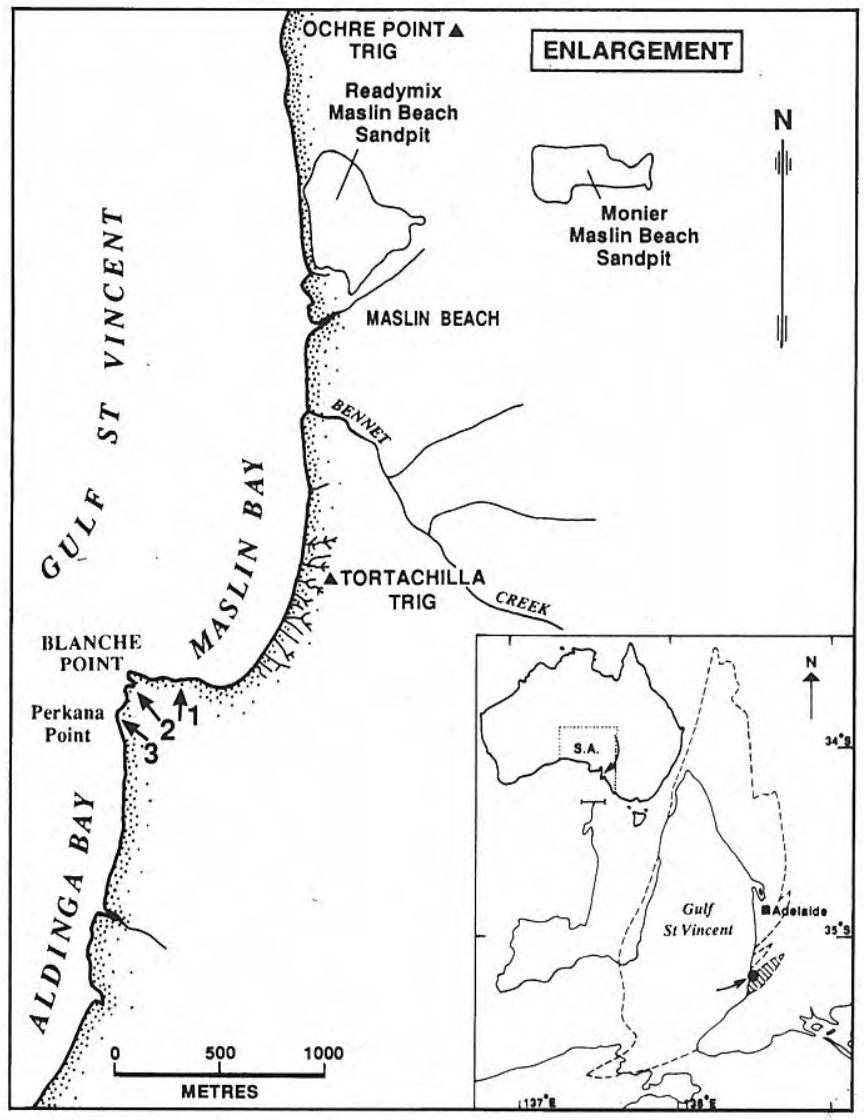

Figure 1. Map showing the locations of the samples collected (indicated by arrows) along the coastal outcrops of Maslin and Aldinga Beaches, eastern St Vincent Basin, South Australia (redrawn from Cooper, 1979 and McKenzie \& Guha, 1987).

Members and describes new ostracod species. The most common ostracod taxa are assessed with a view to interpreting the palaeoecology.

\section{GEOLOGICAL SETTING}

Cooper (1977) formally named the Gull Rock Member which was previously known as the Blanche Point Banded Marls Member (Reynolds, 1953). It is the second member from the base of the highly siliceous Blanche Point Formation. Jenkins et al. (1982) further refined the lithostratigraphical subdivision of the Blanche Point Formation by introducing the Tuketja Member (basal part of the formation), the Perkana Member (above the Gull Rock Member) and the Tuit Member (above the Perkana Member). Variation in the state of the preserved silica is the main basis for discriminating the different members of the Blanche Point Formation. Jones \& Fitzgerald $(1984,1986)$ believe that the abundant silica in the formation was released by the breakdown of volcanic ash produced by volcanism related to the separation of Australia and Antarctica. The presence of several minerals typical of diagenetically altered volcanic ash, and quartz grains showing sharp extinctions and a lack of

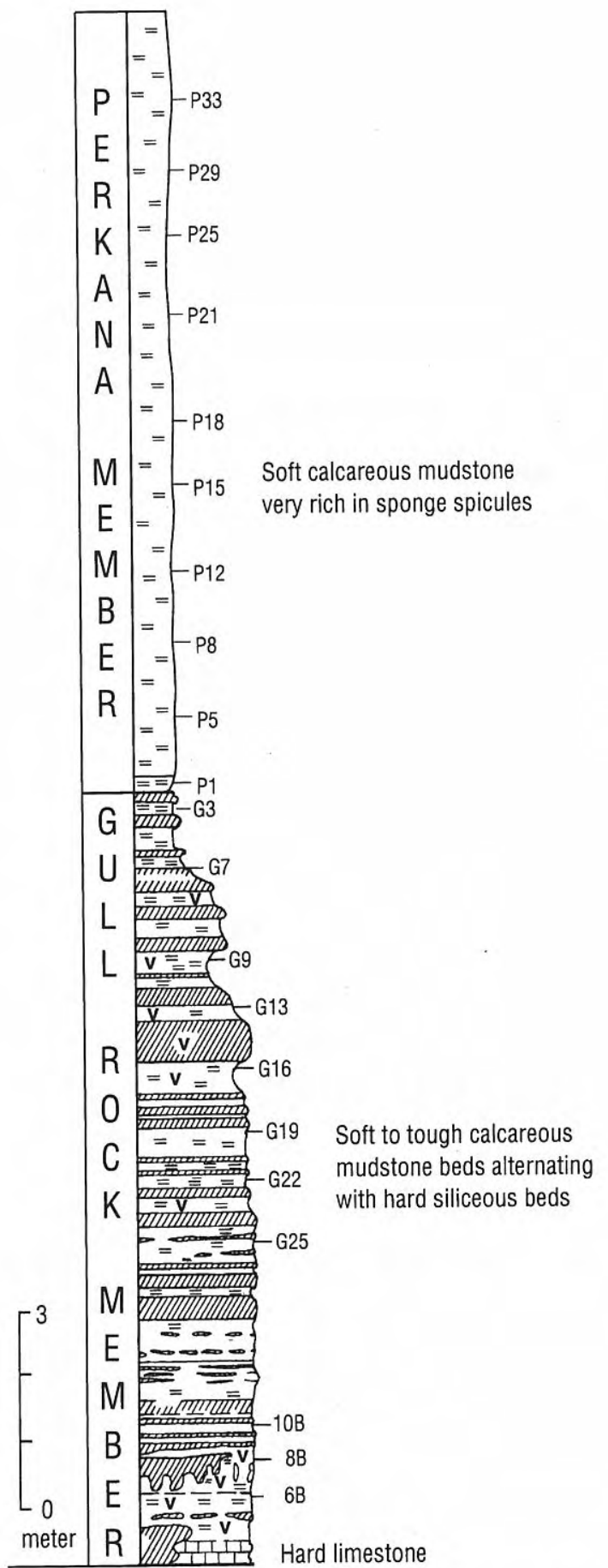

Figure 2. Lithology of the Gull Rock and the Perkana Members with sample sites marked.

mosaic textures, all favour their interpretation. McGowran \& Beecroft (1986) propose a model where the whole St Vincent Basin was episodically covered with thick layers of volcanic ash which then where retained and preserved their due to the (geographically) restricted nature of the St Vincent Basin which was shielded from the open ocean by Kangaroo Island.

As described by McGowran \& Beecroft (1986), the Gull Rock Member (with a total thickness of $11 \mathrm{~m}$ at the type-section; see Reynolds, 1953; Cooper, 1979) 


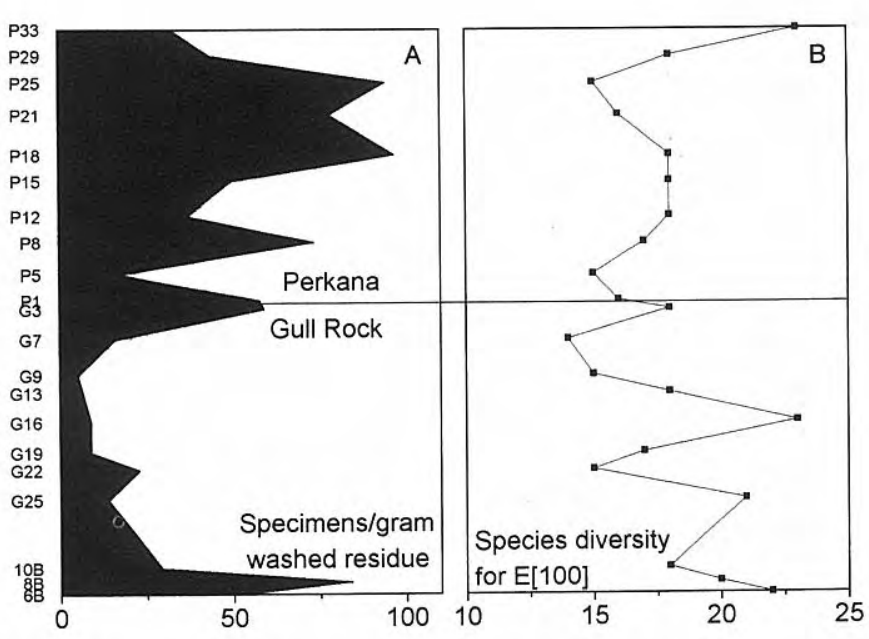

Figure 3. A.Variation in number of ostracods/gram washed residue in the Gull Rock and the Perkana Members. B. Variation in species diversity estimated by Hurlbert's (1971) index. Each sample is standardized to a common sample size of 100 specimens.

comprises 30-35 pairs of alternating hard (silica-rich) and soft (more calcareous) layers. Each individual layer is mostly between $10-50 \mathrm{~cm}$ in thickness. All beds are siliceous (opal-CT) and contain smectite, clinoptilolite and quartz. The hard layers were probably produced diagenetically by selective silification (Jones \& Fitzgerald, 1984, 1986). Glauconite is especially abundant in the basal part of the member, although it is present throughout the entire unit. Aragonite emerges about $8 \mathrm{~m}$ above the base of the member (Jones \& Fitzgerald, 1986). Several horizons yield very large numbers of the gastropod Spirocolpus and are characterized by intense burrowing by solitary corals and various bivalves. The macrofossil faunas are of low diversity, often dominated by infaunal gastropods, although Buonaiuto (1979) defined two molluscan assemblages in this member: a Phygrea assemblage and a Spirocolpus-Dimya-Ledella assemblage.

The Perkana Member has a total thickness of $10.7 \mathrm{~m}$ at the type-section (Jenkins et al., 1982). It is a soft calcareous mudstone without any intervening hard siliceous bands. There is a high content of sponge spicules. Macrofossils are very rare; and according to Buonaiuto (1979) characterized by a LedellaPectunculina-Stiracolpus assemblage.

\section{MATERIAL AND METHODS}

Only the soft layers of the Gull Rock Member were sampled. The lowermost $2 \mathrm{~m}$ of the member was sampled to the west of Blanche Point at the southern end of Maslin Beach, whereas the remainder of this unit and the Perkana Member were collected to the south of Blanche Point on the northern end of Aldinga Beach (Fig. 1). Fig. 2 shows the stratigraphical position of the twenty one samples studied here.
The samples were crushed into small pieces about 2-3 $\mathrm{cm}$ in size, dried in an oven $\left(100^{\circ} \mathrm{C}\right)$ for a few hours, and sieved. Size fractions $\geq 125 \mu \mathrm{m}$ were picked of ostracods. Each valve or carapace represents an individual. The species counts are given in appendices 1-2. Some of the species are preliminary identified. Fig. 3A shows the variation in abundance of ostracods (specimens/gram washed residue) in the two members. Fig. 3B shows the variation in species diversity when each sample is standardized to a common size of 100 individuals by Hurlbert's (1971) index.

\section{THE MOST ABUNDANT OSTRACOD TAXA}

The most common families in the Gull Rock and the Perkana Members include the Cytherellidae, Trachyleberididae, Krithiidae, Pontocyprididae, Bythocyprididae, Paracyprididae and Cytheruridae. Figs. 4-5 show the variation in relative and absolute abundance of these families in the two members. Fig. 6 shows the corresponding variation in relative abundance of 14 of the most abundant species.

1. The family Cytherellidae is largely dominated by Cytherella gullrockensis McKenzie, Reyment \& Reyment, (Pl. I, Fig. 1) which is the most abundant species in the present fauna. It is most abundant at the base of the Gull Rock Member. Cytherelloidea jugifera McKenzie, Reyment \& Reyment, (Pl. I, Fig. 2) is also common in the Gull Rock Member, particularly in the upper part of the latter member (Fig. 6).

2. The family Trachyleberididae is dominated by Trachyleberis thomsoni (Hornibrook) (Pl. I, Fig. 13) in the basal half of the Gull Rock Member (Fig. 6), whereas Trachyleberis maslinensis sp. nov. (Pl. II, Figs. 1-4) is the dominant trachyleberidid in the Perkana Member (Fig. 6). Echinocythereis karooma McKenzie, Reyment \& Reyment (Pl. I, Fig. 9) is particularly abundant in the basal part of the Perkana Member (Fig. 6).

3. The family Krithiidae is represented only by Krithe postcircularis McKenzie, Reyment \& Reyment, which becomes abundant in samples above the basal part of the Gull Rock Member (Fig. 6). Sexual dimorphism seems very prominent in this species and includes the shape of the posterior region which is more circular in females ( $\mathrm{Pl}$. I, Figs. 10-11). There is also some variation in size. This was also observed in the type material by McKenzie et al. (1993).

4. The family Pontocyprididae is almost completely dominated by Argilloecia spp. and Maddocksella tarparriensis McKenzie, Reyment \& Reyment (see Pl. I, Fig. 4). Argilloecia spp. include about 180 specimens from the Gull Rock and the Perkana Members, many of which are juveniles. The few small specimens of the lower part of the Gull Rock Member probably belong to a single taxon. However, the more numerous specimens encountered in the upper part of the Gull Rock Member and in the Perkana Member probably belong to more than one species. It is, however, extremely difficult to define species and determine the affinity among the many small 


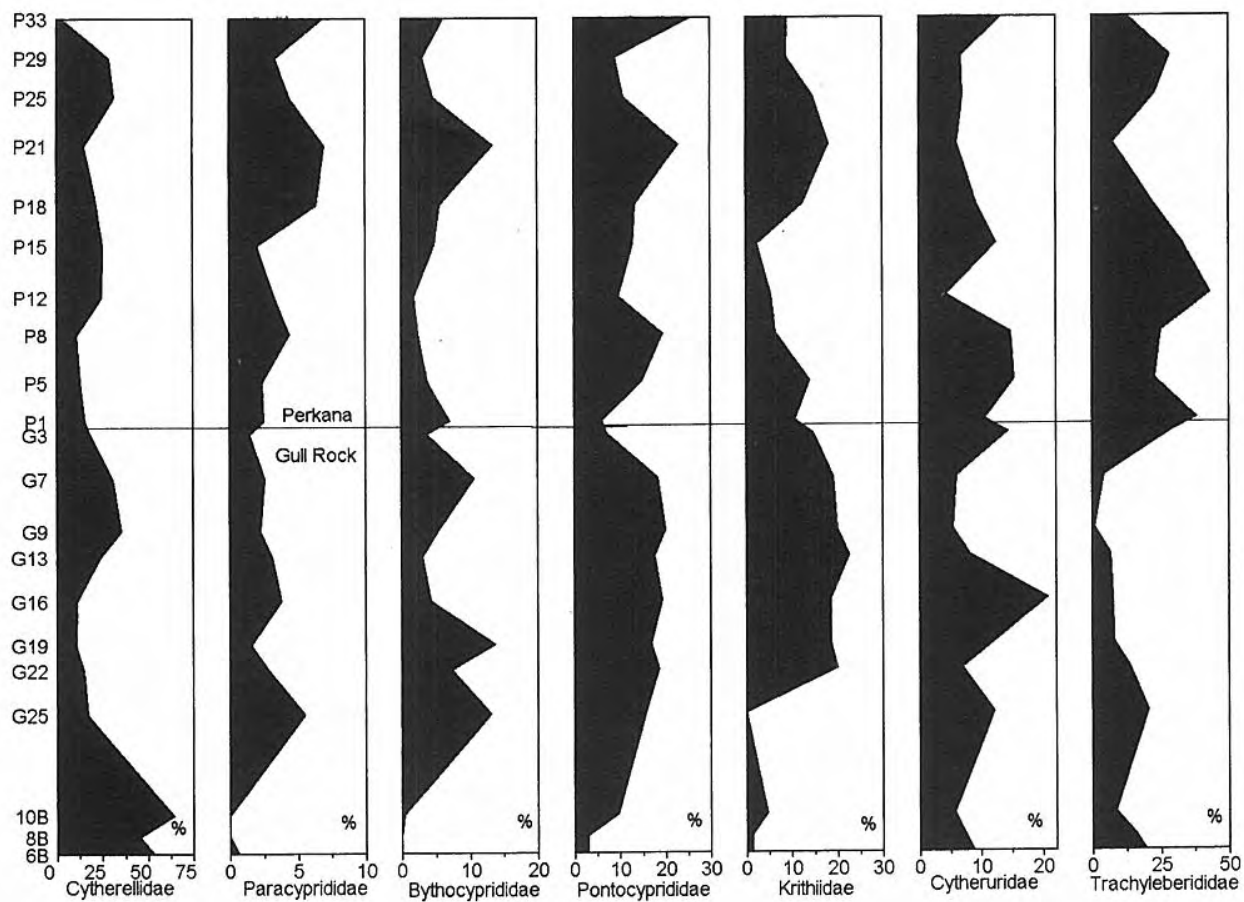

Figure 4. Variation in relative abundance $(\%)$ of selected ostracod families in the Gull Rock and the Perkana Members.

'argilloecid' forms recorded. They cannot clearly be differentiated and are, therefore, grouped under Argilloecia spp.

5. The family Bythocyprididae is mainly represented by Bythocypris sudaustralis McKenzie, Reyment \& Reyment (Pl. I, Fig. 14). It is relatively abundant (fluctuating) in samples above the base of the Gull Rock Member (Fig. 6).

6. The family Paracyprididae is represented by Paracypris aff. bradyi (see Pl. II, Fig. 7 of McKenzie et al., 1991) and Tasmanocypris? sp. The latter species is common only in the Perkana Member. Its internal features are clearly paracypridid. It is very similar to Tasmanocypris eurylamella McKenzie, Reyment \& Reyment, with respect to external shape and internal features but is somewhat smaller in size.

7. The family Cytheruridae includes many Kangarina wareelacogarra McKenzie, Reyment \& Reyment (Pl. I, Fig. 5), Oculocytheropteron australopunctatarum McKenzie, Reyment \& Reyment (Pl. I, Fig. 7), Oculocytheropteron cf. microfornix Whatley \& Downing (Pl. I, Fig. 8), and Aversovalva spp. (Pl. I, Fig. 6). O. cf. microfornix is a provisional assignment for specimens which are small and with many juveniles (difficult to identify), which may be closer to Oculocytheropteron aviformum McKenzie, Reyment \& Reyment, and Oculocytheropteron tinctum McKenzie, Reyment \& Reyment. Aversovalva spp. is a provisional assignment for many small forms which are difficult to differentiate under the light microscope. They are in need of further taxonomic treatment. At least two species are included one of which seems to belong to Aversovalva nairana McKenzie, Reyment \& Reyment.

\section{BIOZONATION}

Fig. 6 suggests that there is a relationship between the lithostratigraphy of the two members and the abundance of some of the most common ostracod species. This relationship may be used to define a local ostracod assemblage zone for each of the two members. The most significant features of the Gull Rock Ostracod Assemblage are $C$. jugifera, $M$. tarparriensis (with two peaks), $T$. thomsoni and $O$. cf. microfornix. The most characteristic features of the Perkana Ostracod Assemblage are T. maslinensis sp. nov., Tasmanocypris? sp., Aversovalva spp., O. australopunctatarum and E. karooma.

\section{TAPHONOMY AND PALAEOECOLOGY}

1. McGowran \& Beecroft (1986, p. 336) estimated the time taken for the deposition of the present thickness of the Blanche Point Formation ( $30 \mathrm{~m}$ ) to about $1.5 \mathrm{~m} . \mathrm{y}$. This estimation corresponds to relatively slow sedimentation rates (with a mean of $2-3 \mathrm{~cm} / 1000$ year). If this estimation of slow sedimentation rates is correct, it may well be the main reason for the very high proportion of disarticulated valves found among the ostracods. The proportion of disarticulated valves in a fossil ostracod assemblage is largely dependent on the sedimentation rate, but also on energy levels post mortem (Whatley, 1988). Except for the basal samples of the Gull Rock Member, the number of specimens/g sediment is generally lower in the latter member than in the Perkana Member (Fig. 3A). This is possibly due to higher sedimentation rates and/or lower population densities in the Gull Rock Member. 
2. Species with age structures comprising adults with a full suite of moults are generally regarded as autochthonous, whereas taxa represented only by adults and the A-1 stage may either be part of a high energy biocoenosis or a gradational thanatocoenosis (Whatley, 1988). If only the most abundant species are considered (Table 1), C. gullrockensis and C. jugifera (with 6-7 ontogenetic stages present), and B. sudaustralis (with 4-5 ontogenetic stages present), are most certainly autochthonous. This is possibly also the case for species with three ontogenetic stages present (e.g. $K$. postcircularis, Argilloecia spp., Aversovalva spp., $T$. thomsoni, T. maslinensis sp. nov., B. willungaensis sp. nov., and $M$. tarparriensis). Also, some of the smaller species with only one or two ontogenetic stages present may well be autochthonous (e.g. Kuiperiana lindsayi, $O$. australopunctatarum, $O$. cf. microfornix and $K$. wareelacogarra) since as sedimentary particles their small size is comparable to younger instar stages of larger species.

3. McKenzie (1979) interpreted the Gull Rock Member equivalent in the Willunga Embayment boreholes as indicating an outer shelf environment with depths around 75-100 m, mainly on the basis of the many C. gullrockensis which belongs to a group of large smooth cytherellids which tend to typify outer shelf or deepwater assemblages (McKenzie, 1979; McKenzie et al., 1991). Similar depths may also be inferred from the low representation of xestoleberidids and hemicytherids.
C. gullrockensis and T. thomsoni dominate the three basal samples of the Gull Rock Member. T. thomsoni occurs in the Recent of the eastern Tasman Sea generally at depths greater than $100 \mathrm{~m}$ (Swanson, 1979; Swanson, unpubl. data). However, compared to the three basal samples of the Gull Rock Member, there is a higher relative abundance of Krithe, pontocypridids (with many Argilloecia) and bythocypridids (Bythocypris) in the subsequent samples studied that may well signify deeper conditions (Fig. 4). The latter three genera generally indicate deep water, epibathyal depths exceeding $100 \mathrm{~m}$, although Krithe may occur also in shallower depths. Of interest is also the clear peak in the relative and absolute abundance of bythocypridids, pontocypridids, paracypridids and krithiids in samples P18-P25 of the Perkana Member (Figs. 4-5). This interval is also associated with a corresponding negative peak in cytherellids, trachyleberidids and cytherurids (Figs. 4-6). This is probably of palaeoenvironmental significance and possibly linked to a fluctuating sea level, although this is a speculation.

4. According to McGowran \& Beecroft (1986), the foraminiferal biofacies indicates that the Blanche Point Formation was accumulated in some kind of stressed environment, possibly connected to low oxygen values. They related two uvigerinid foraminiferal peaks at $0-2.5$ $\mathrm{m}$ and 7-10 m, respectively, above the base of the Gull Rock Member, to increased $\mathrm{O}_{2}$ minimum conditions (McGowran \& Beecroft, 1986, Fig. 6). Subsequently, the

\section{Plate I}

$1 \quad$ Cytherella gullrockensis McKenzie, Reyment \& Reyment. Female LV. Late Eocene, Gull Rock Member. DMGUG.Au.1. x 50.

2 Cytherelloidea jugifera McKenzie, Reyment \& Reyment. Female RV. Late Eocene, Gull Rock Member. DMGUG.Au.2. x 48.

$3 \quad$ Kuiperiana lindsayi (McKenzie, Reyment \& Reyment). RV. Late Eocene, Perkana Member. DMGUG.Au.3. x 120.

$4 \quad$ Maddocksella tarparriensis McKenzie, Reyment \& Reyment. Female LV. Late Eocene, Perkana Member. DMGUG.Au.4. x 57.

$5 \quad$ Kangarina wareelacogarra McKenzie, Reyment \& Reyment. LV. Late Eocene, Gull Rock Member. DMGUG.Au.5. x 120.

6 Aversovalva sp. RV. Late Eocene, Gull Rock Member. DMGUG.Au.6. x 120.

7 Oculocytheropteron australopunctatarum McKenzie, Reyment \& Reyment. RV. Late Eocene, Perkana Member. DMGUG.Au.7. x 75.

8 Oculocytheropteron cf. microfornix Whatley \& Downing. LV. Late Eocene, Gull Rock Member. DMGUG.Au.8. x 90.

9 Echinocythereis karooma McKenzie, Reyment \& Reyment. RV. Late Eocene, Perkana Member. DMGUG.Au.9. x 60.

10-11 Krithe postcircularis McKenzie, Reyment \& Reyment. 10. Female RV. Late Eocene, Perkana
Member. DMGUG.Au.10. x 60. $\Delta$ 11. Male RV. Late Eocene, Perkana Member. DMGUG.Au.11. x 60.

12 Quasibradlena cf. mamitea. McKenzie, Reyment \& Reyment. Female LV. Late Eocene, Gull Rock Member. DMGUG.Au.12. x 60.

13 Trachyleberis thomsoni Hornibrook. Female LV. Late Eocene, Gull Rock Member. DMGUG.Au.13. x 48.

14 Bythocypris sudaustralis McKenzie, Reyment \& Reyment. RV. Late Eocene, Gull Rock Member. DMGUG.Au.14. x 42.

15 Actinocythereis cf. probesioides (Hornibrook). LV. Late Eocene, Perkana Member. DMGUG.Au.15. x 48.

16-22 Bairdoppilata willungaensis sp. nov. 16. LV internal view (paratype). Late Eocene, Gull Rock Member. DMGUG.Au.16. x 32. $\Delta$ 17. RV (holotype). Late Eocene, Gull Rock Member. DMGUG.Au.17. x 36. $\Delta 18 . \mathrm{RV}$ internal view (paratype). Late Eocene, Gull Rock Member. DMGUG.Au.18. x 36. $\Delta$ 19. LV (paratype). Late Eocene, Gull Rock Member. DMGUG.Au.19. x 32. $\Delta$ 20. RV internal view of muscle-scars, x 120 (paratype). Late Eocene, Gull Rock Member. DMGUG.Au.18. $\Delta$ 21. RV internal view of the anterior 'bairdoppilat' crenulation, x 120 (paratype). Late Eocene, Gull Rock Member. DMGUG.Au.18. $\triangle 22$. RV internal view of the posterior 'bairdoppilat' crenulation, x 120 (paratype). Late Eocene, Gull Rock Member. DMGUG.Au.18. 
Plate I

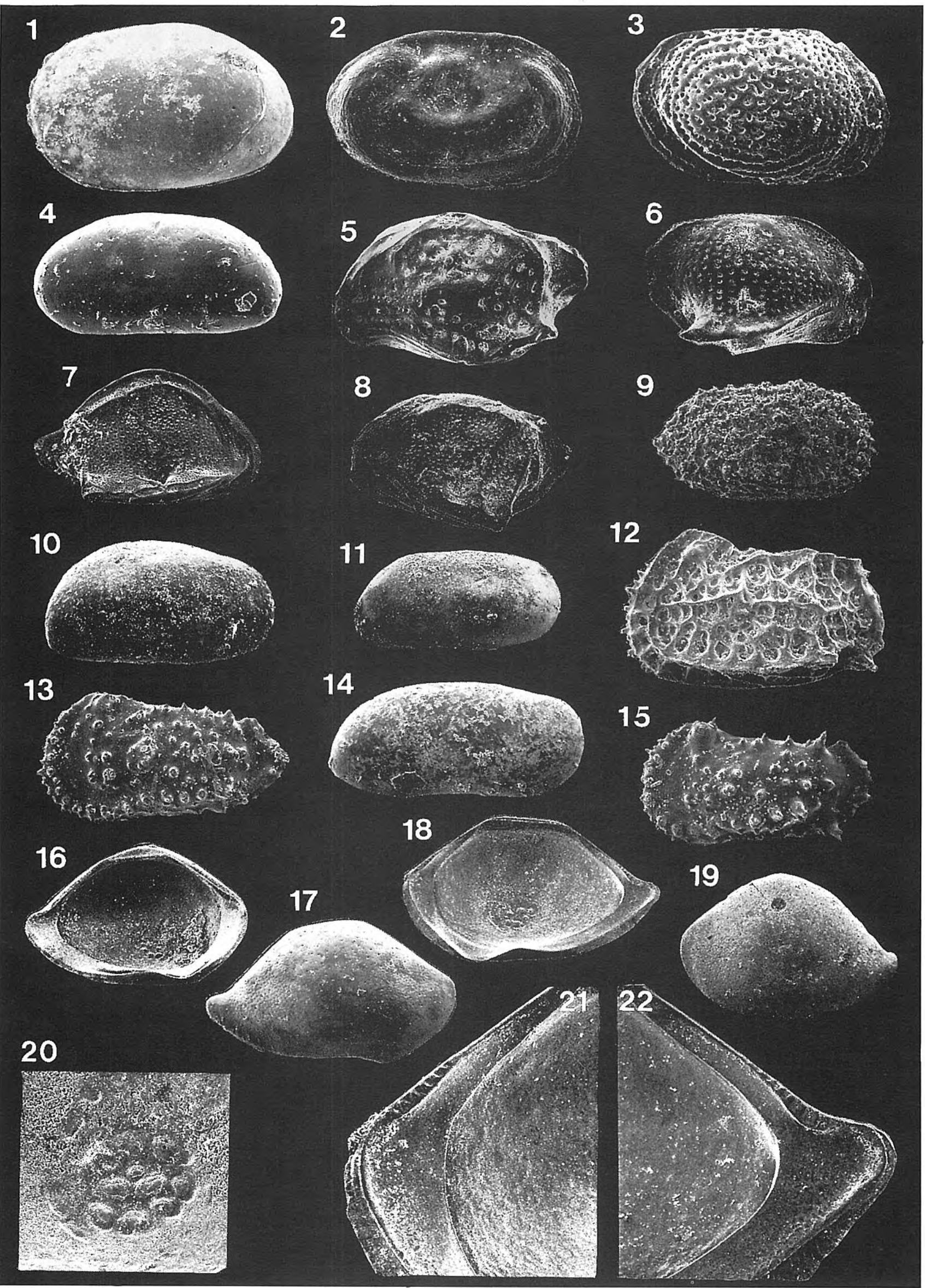

Revista Española de Paleontología, 11(1), 1996. 


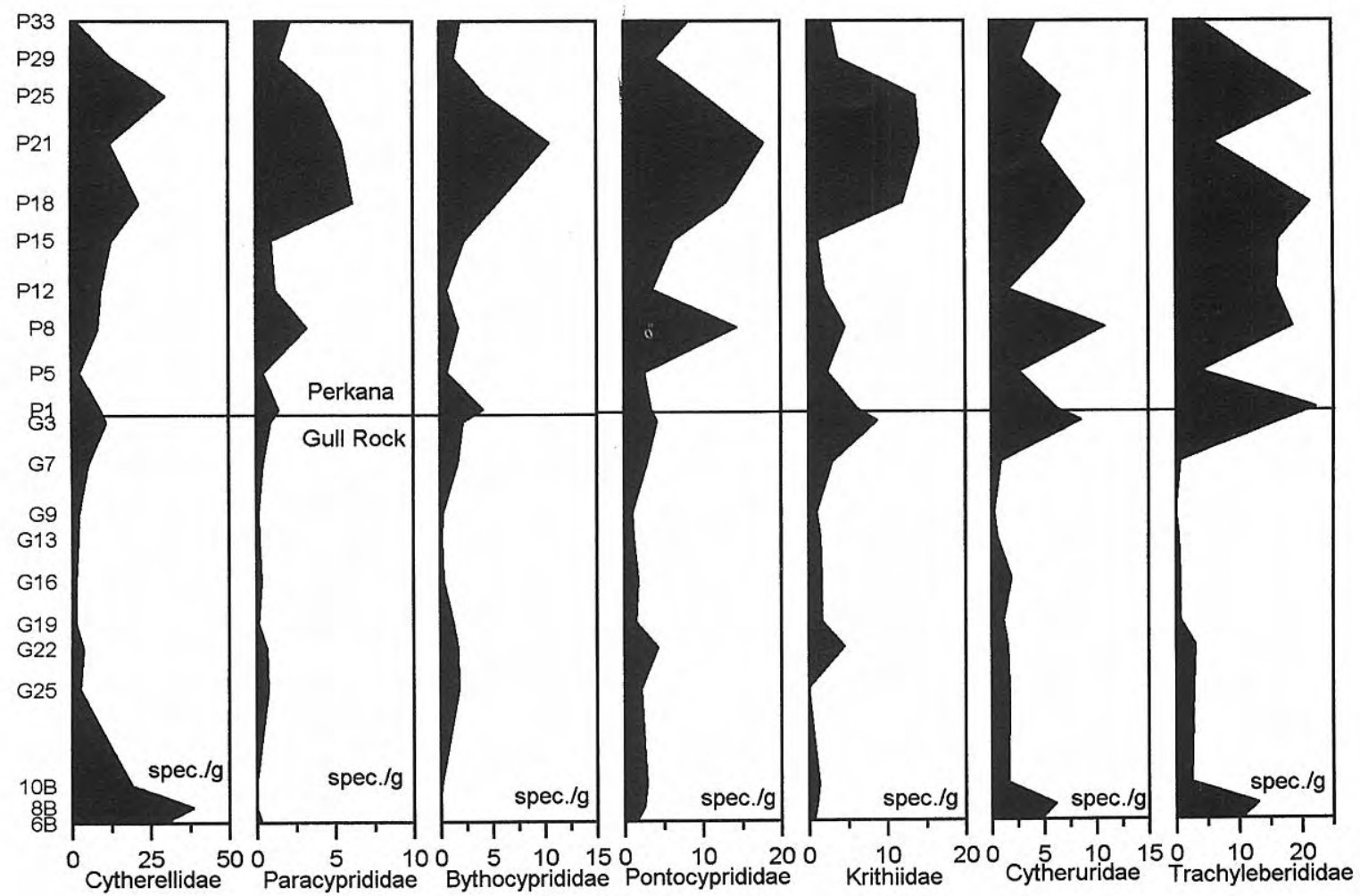

Figure 5. Variation in absolute abundance (number of specimens/gram washed residue) of selected ostracod families in the Gull Rock and the Perkana Members.

use of uvigerinids as indicators of low oxygen levels has been questioned since data from the Indian Ocean reveals that the percentage of Uvigerina can vary independently of dissolved oxygen content in deep water (Corliss et al., 1986). There is, however, a corresponding peak in the abundance of cytherellid ostracods in the basal $2.5 \mathrm{~m}$ of the Gull Rock Member (also to a lesser extent within the interval between $7-10 \mathrm{~m}$ above the base where a peak in $C$. jugifera occurs; Figs. 4-6) which may possibly suggest an increase in the intensity of oxygen minimum conditions in these intervals (Figs. 4-5). Whatley (1991) and Boomer \& Whatley (1992) have shown that cytherellids have a greater ability to flourish and survive in low oxygen environments compared to podocopids due to their filter feeding habit. The species diversity (of all species) is, however, not lower during these peaks (Fig. 3B).

\section{PALAEOBIOGEOGRAPHIC NOTE}

Table 2 shows the species identified in this study that have been recorded from elsewhere. This is without further trying to resolve the taxa here preliminary identified as Aversovalva spp. and Oculocytheropteron cf. microfornix. Twenty three of the present species occur in the palaeogene of Victoria, Australia, of which most are described by McKenzie et al. (1991, 1993). Actinocythereis probesioides (Hornibrook) (Pl. I, Fig. 15) was previously only known from the Neogene of New Zealand (see Hornibrook, 1952) but recently recorded also from the palaeogene of Victoria by McKenzie et al.,
(1991; p. 169). Except for the latter species, three of the present species may be conspecific with species occurring in the palaeogene of New Zealand (see Hornibrook, 1952; Ayress, 1993a): T. thomsoni Hornibrook (Pl. I, Fig. 13); Anebocythereis hostizea? (Hornibrook) (very similar to Rugocythereis multiflora McKenzie, Reyment \& Reyment); and small forms identified as Eucythere parapubera? Whatley \& Downing (see Ayress, 1993a).

\section{SYSTEMATIC DESCRIPTIONS}

Only some of the new taxa recorded are systematically described here. Six are described as new, and one left in open nomenclature due to rarity. All measurements were made using a microprocessor controlled image digitizer connected to a light microscope. The following abbreviations are used: $\mathrm{RV}=$ right valve, $\mathrm{LV}=$ left valve, $\mathrm{L}=$ length and $\mathrm{H}=$ height. $\mathrm{L}$ and $\mathrm{H}$ for holotypes and paratypes are appended to the descriptions. All figured specimens are housed in the Department of Marine Geology, University of Göteborg; the storage code is DMGUG.Au (catalogue numbers 1-18 and 45-67).

CLASS OSTRACODA Latreille, 1806 ORDER PODOCOPIDA Müller, 1894 SUBORDER PODOCOPINA Sars, 1866 Superfamily BAIRDIACEA Sars, 1888 Family Bairdiidae Sars, 1888

Genus Bairdoppilata Coryell, Sample \& Jennings, 1953 


\begin{tabular}{|c|c|c|c|c|c|c|c|c|c|c|c|c|c|c|c|c|c|c|c|c|c|}
\hline MEMBER: & \multicolumn{11}{|c|}{ GULL ROCK MEMBER } & \multicolumn{10}{|c|}{ PERKANA MEMBER } \\
\hline SpeciesISample: & $6 \mathrm{~B}$ & $8 \mathrm{~B}$ & $10 \mathrm{~B}$ & G25 & $\mathrm{G} 22$ & G19 & $\overline{\mathrm{G} 16}$ & $\mathrm{Gl3}$ & G9 & G7 & G3 & $\mathrm{P} 1$ & P5 & $\mathrm{P} 8$ & P12 & $\mathrm{P} 15$ & P18 & $\mathrm{P} 21$ & $\mathrm{P} 25$ & $\mathrm{P} 29$ & $\mathrm{P} 33$ \\
\hline Cytherella gullrockensis & $\mathrm{A}$ & A & $\mathrm{A}$ & $\mathrm{A}$ & $\bar{A}$ & $\mathrm{C}$ & $\mathrm{C}$ & $\mathrm{A}$ & $\mathrm{A}$ & $\mathrm{A}$ & A & $\mathrm{A}$ & A & $\mathrm{A}$ & $\mathrm{A}$ & $\mathrm{A}$ & $\mathrm{A}$ & A & $\mathrm{A}$ & $\mathrm{A}$ & $\mathrm{R}$ \\
\hline Cytherelloidea jugifera & $\mathrm{R}$ & $\mathrm{C}$ & $\mathrm{C}$ & $\mathrm{R}$ & $\mathrm{R}$ & $\mathrm{C}$ & A & $\mathrm{C}$ & $\mathrm{C}$ & A & A & $\mathrm{C}$ & $\mathrm{R}$ & $\mathrm{C}$ & $\mathrm{R}$ & & & & & & \\
\hline Kuiperiana lindsayi & $\mathrm{C}$ & $\mathrm{C}$ & $\mathrm{C}$ & $\mathrm{C}$ & A & A & $\mathrm{A}$ & $\mathrm{C}$ & $\mathrm{C}$ & $\mathrm{C}$ & $\mathrm{C}$ & $\mathrm{A}$ & A & $\mathrm{C}$ & $\mathrm{C}$ & & $\mathrm{C}$ & & $\mathrm{R}$ & $\mathrm{R}$ & $\mathrm{A}$ \\
\hline Maddocksella tarparriensis & $\mathrm{R}$ & $\mathrm{C}$ & A & A & $\mathrm{C}$ & $\mathrm{C}$ & $\mathrm{A}$ & $\mathrm{C}$ & $\mathrm{C}$ & $\mathrm{R}$ & $\mathrm{C}$ & $\mathrm{C}$ & $\mathrm{R}$ & $\mathrm{C}$ & $\mathrm{C}$ & $\mathrm{R}$ & $\mathrm{C}$ & $\mathrm{C}$ & $\mathrm{C}$ & $\mathrm{R}$ & A \\
\hline Kangarina wareelacogarra & $\mathrm{C}$ & $\mathrm{R}$ & $\mathrm{R}$ & $\mathrm{C}$ & $\mathrm{R}$ & $\mathrm{R}$ & $\mathrm{C}$ & $\mathrm{R}$ & $\mathrm{R}$ & $\mathrm{R}$ & $\mathrm{R}$ & & & & & $\mathrm{R}$ & $\mathrm{R}$ & & & $\mathrm{R}$ & $\mathrm{R}$ \\
\hline Aversovalva spp. & $\mathrm{C}$ & $\mathrm{R}$ & $\mathrm{R}$ & $\mathrm{R}$ & & $\mathrm{R}$ & $\mathrm{C}$ & $\mathrm{R}$ & $\mathrm{R}$ & $\mathrm{R}$ & $\mathrm{C}$ & & $\mathrm{C}$ & A & $\mathrm{C}$ & $\mathrm{C}$ & $\mathrm{C}$ & $\mathrm{C}$ & $\mathrm{C}$ & $\mathrm{C}$ & $\mathrm{R}$ \\
\hline Oculocytheropteron australopunct. & $\mathrm{R}$ & $\mathrm{R}$ & $\mathrm{R}$ & $\mathrm{C}$ & $\mathrm{R}$ & $\mathrm{R}$ & $\mathrm{C}$ & $\mathrm{C}$ & $\mathrm{R}$ & $\mathrm{C}$ & A & A & A & A & $\mathrm{C}$ & $\mathrm{A}$ & A & $\mathrm{R}$ & $\mathrm{C}$ & $\mathrm{C}$ & $\mathrm{R}$ \\
\hline Oculocytheropteron cf. microfornix & $\mathrm{R}$ & $\mathrm{C}$ & $\mathrm{R}$ & $\mathrm{C}$ & $\mathrm{C}$ & A & $\mathrm{C}$ & $\mathrm{R}$ & & $\mathrm{R}$ & & & $\mathrm{R}$ & $\mathrm{R}$ & & $\mathrm{R}$ & $\mathrm{R}$ & & $\mathrm{R}$ & $\mathrm{R}$ & A \\
\hline Echinocythereis karooma & $\mathrm{C}$ & $\mathrm{R}$ & $\mathrm{R}$ & $\mathrm{R}$ & $\mathrm{R}$ & $\mathrm{R}$ & $\mathrm{R}$ & $\mathrm{R}$ & & & A & $\mathrm{A}$ & A & $\mathrm{A}$ & $\mathrm{A}$ & A & & & & & \\
\hline Bairdoppilata willungaensis sp. nov. & $\mathrm{C}$ & A & $\mathrm{C}$ & $\mathrm{C}$ & & $\mathrm{C}$ & $\mathrm{R}$ & & & & $\mathrm{R}$ & & $\mathrm{R}$ & $\mathrm{R}$ & $\mathrm{R}$ & $\mathrm{R}$ & & $\mathrm{C}$ & $\mathrm{R}$ & $\mathrm{C}$ & $\mathrm{R}$ \\
\hline Trachyleberis thomsoni & A & A & $\mathrm{R}$ & A & A & $\mathrm{C}$ & $\mathrm{C}$ & & & & & & & & & & & & & & \\
\hline Trachyleberis maslinensis sp. nov. & $\mathrm{C}$ & $\mathrm{R}$ & & & & & & $\mathrm{R}$ & $\mathrm{R}$ & $\mathrm{C}$ & A & A & $\mathrm{A}$ & A & A & A & $\mathrm{A}$ & $\mathrm{A}$ & A & A & A \\
\hline Krithe postcircularis & $\mathrm{R}$ & $\mathrm{R}$ & $\mathrm{C}$ & & A & A & $\mathrm{A}$ & $\mathrm{A}$ & A & A & A & A & A & $\mathrm{A}$ & A & $\mathrm{C}$ & A & A & A & A & A \\
\hline Argilloecia spp. & $\mathrm{R}$ & $\mathrm{R}$ & $\mathrm{C}$ & $\mathrm{C}$ & A & $\mathrm{A}$ & A & $\mathrm{C}$ & A & A & $\mathrm{C}$ & $\mathrm{C}$ & A & $\mathrm{A}$ & A & $\mathrm{A}$ & A & A & A & A & A \\
\hline Bythocypris sudaustralis & & & $\mathrm{R}$ & $\mathrm{A}$ & $\mathrm{C}$ & $\mathrm{A}$ & $\mathrm{C}$ & $\mathrm{R}$ & $\mathrm{C}$ & $\mathrm{A}$ & $\mathrm{C}$ & $\mathrm{A}$ & $\mathrm{C}$ & $\mathrm{C}$ & $\mathrm{C}$ & $\mathrm{C}$ & A & $\mathrm{A}$ & A & $\mathrm{C}$ & $\mathrm{C}$ \\
\hline Paracypris aff. bradyi & & & & $\mathrm{C}$ & $\mathrm{C}$ & $\mathrm{R}$ & $\mathrm{C}$ & $\mathrm{R}$ & $\mathrm{R}$ & $\mathrm{C}$ & $\mathrm{R}$ & $\mathrm{R}$ & $\mathrm{R}$ & $\mathrm{R}$ & $\mathrm{R}$ & $\mathrm{R}$ & $\mathrm{C}$ & $\mathrm{C}$ & $\mathrm{C}$ & $\mathrm{R}$ & $\mathrm{C}$ \\
\hline Quasibradleya cf. momitea & & & & $\mathrm{C}$ & $\mathrm{R}$ & & & & & $\mathrm{R}$ & $\mathrm{A}$ & $\mathrm{R}$ & $\mathrm{R}$ & $\mathrm{A}$ & $\mathrm{R}$ & & $\mathrm{R}$ & & & & \\
\hline
\end{tabular}

Table 1. Range chart for the most common ostracod species in the Gull Rock and Perkana Members. The following abundancy designations are used: "R" = 1-5 specimens, "C" = 6-15 specimens and "A" $\geq 15$ specimens.

\section{Bairdoppilata willungaensis sp. nov. Pl. I, figs. 16-22}

Derivation of name: From the town Port Willunga near the type locality.

Holotype: The RV specimen DMGUG.Au.1\%. Pl. I, Fig. 17.

Type locality: Type section of the late Eocene Blanche Point Formation. Holotype from approximately $2 \mathrm{~m}$ above the base of the Gull Rock Member. Paratypes: DMGUG.Au.16, 19-22; Pl. I, Figs. 16, 19-22.

\section{Diagnosis}

A finely punctate species of Bairdoppilata with a prominent caudal process and a concave dorso-caudal inflexure in both valves; a moderately broad inner lamella with a narrow vestibulum.

\section{Description}

Carapace thick-shelled and large with a finely punctate surface; subtrapetzoidal to subtriangular in lateral view, terminating posteriorly with a prominent caudal process; greatest height at mid-length, greatest length below midheight. Fusiform to elliptical in dorsal view; greatest width at mid-length. LV larger than RV and overlapping the latter most conspicuously mid-dorsally and mid-ventrally. Dorsal margin highly arched in the LV, tripartite with straight segments in the RV; terminating posteriorly with a concave dorsocaudal inflexure in both valves. Ventral margin convex antero- and posteroventrally; faintly concave mid-ventrally in the RV, substraight in the LV. Internal characters with a moderately broad inner lamella and a distinct selvage which is sinuous ventrally. Vestibule narrow. Marginal pore canals numerous, simple and straight. Hinge short adont, but with auxiliary dentition dorsocaudally and anterodorsally as is the hallmark of the genus. Central muscle-scars with 9-10 rounded scars in a subcircular aggregate. Sexual dimorphism not confirmed by visual inspection of the specimens.
Dimensions (mm): The RV ranges in $\mathrm{L}$ from 1.19-1.26 and in $\mathrm{H}$ from $0.67-0.73$, whereas the $\mathrm{LV}$ ranges in $\mathrm{L}$ from 1.211.33 and in $\mathrm{H}$ from 0.78-0.87. Holotype, DMGUG.Au.17 (RV), $\mathrm{L}=1.26, \mathrm{H}=0.73$. Paratype, DMGUG.Au.16 (LV), $\mathrm{L}=$ 1.22, $\mathrm{H}=0.78$. Paratype, DMGUG.Au.18 (RV), $\mathrm{L}=1.22, \mathrm{H}=$ 0.69. Paratype, DMGUG.Au.19 (LV), $\mathrm{L}=1.31, \mathrm{H}=0.86$.

\section{Remarks}

The Miocene Bairdoppilata fyansfordensis Warne, from the Fyansford Formation (Warne, 1988), Victoria, Australia, is very similar in overall morphology (including size) to the new species but may be distinguished from the latter by the lateral compression of the anteriormost part of the carapace.

\section{Material}

About 136 specimens from the Gull Rock and the Perkana Members.

Superfamily CYTHERACEA Baird, 1850

Family Trachyleberididae Sylvester-Bradley, 1948 Genus Trachyleberis Brady, 1898

\section{Trachyleberis maslinensis sp. nov. Pl. II, figs. 1-4}

Derivation of name: From Maslin Beach where the basal half of the Blanche Point Formation outcrops.

Holotype: The female LV specimen DMGUG.Au.45., Pl. II, fig. 1.

Type locality: The type section of the late Eocene Blanche Point Formation. Holotype from approximately $7.5 \mathrm{~m}$ above the base of the Perkana Member. Paratypes: DMGUG.Au.4648; Pl. II, figs. 2-4.

\section{Diagnosis}

A species of Trachyleberis with prominent sexual 

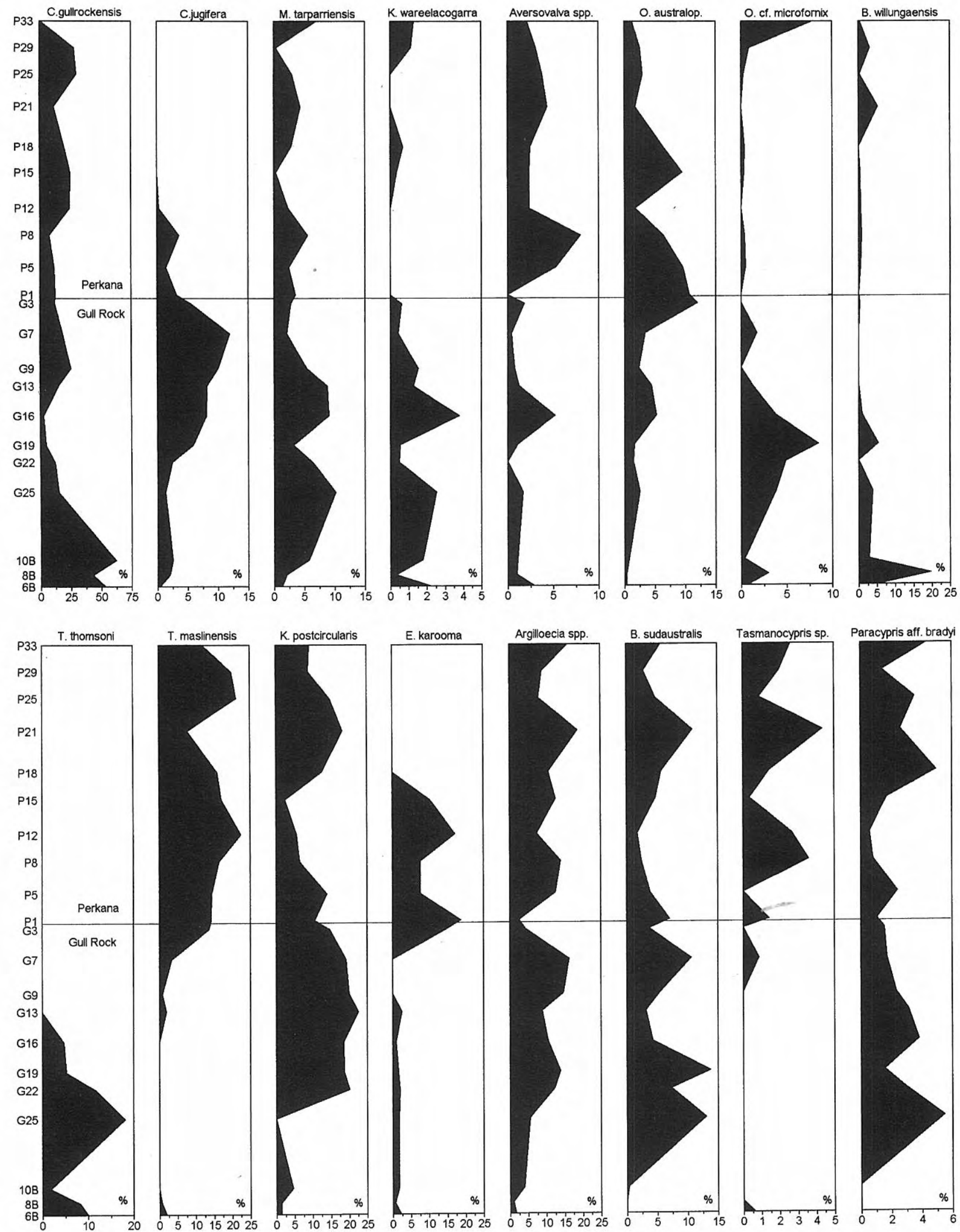

Figure 6. Variation in relative abundance (\%) of 14 of the most abundant species in the Gull Rock and the Perkana Members.

dimorphism and a lateral surface covered with an extraordinary dense ornamentation of morphologically variably spines or tubercles developed as small papillae, very slender spines or more powerful tubercles with a central pore surrounded by a distal furcation.

\section{Description}

Carapace of medium size, subrectangular; sexual dimorphism prominent with males more elongate. Greatest length at mid-height. Greatest height slightly anterior to the distinct eye-tubercle. Anterior margin evenly rounded and 


\begin{tabular}{|c|c|c|c|}
\hline Species\Geographical region & \multicolumn{2}{|c|}{ Australia } & New Zealand \\
\hline & South Australia & Victoria & \\
\hline Cytherelloidea marginopytta & $\mathrm{X} ?$ & $\mathrm{X}$ & \\
\hline Bairdoppilata willungaensis sp. nov. & $\mathbf{x}$ & $\mathbf{X}$ & \\
\hline Bythocypris sudaustralis & $\mathrm{X}$ & $\mathbf{x}$ & \\
\hline Argilloecia spp. & $\mathrm{x}$ & $\mathbf{X}$ & \\
\hline Maddocksella tarparriensis & $\mathrm{x}$ & $\mathbf{x}$ & \\
\hline Trachyleberis thomsoni & $\mathrm{X}$ & $\mathrm{x}$ & $\mathrm{x}$ \\
\hline Trachyleberis paucispinosa & $\mathrm{X}$ & $\mathrm{X}$ & \\
\hline Actinocythereis probesioides & cf. $X$ & cf. $x$ & $\mathrm{X}$ (Neogene) \\
\hline Anebocythereis hostizea & $\mathrm{X}$ ? & $\mathrm{X}$ ? & $\mathrm{x}$ \\
\hline Deltaleberis delicata & $\mathrm{X}$ ? & $\mathbf{x}$ & \\
\hline Echinocythereis karooma & $\mathrm{x}$ & $\mathbf{X}$ & \\
\hline Cletocythereis taroona & $\mathbf{X}$ & $\mathrm{x}$ & \\
\hline Quasibradleya momitea & cf. $X$ & $\mathbf{x}$ & \\
\hline Krithe postcircularis & $\mathbf{x}$ & $\mathbf{x}$ & \\
\hline Eucythere parapubera & $\mathrm{X}$ ? & $\mathrm{x}$ & $\mathrm{x}$ \\
\hline Arcacythere sp. & $\mathrm{X}$ & $\mathrm{x}$ & \\
\hline Munseyella dunoona & $\mathrm{x}$ & $\mathbf{x}$ & \\
\hline Munseyella pytta & $\mathrm{x}$ & $\mathrm{x}$ & \\
\hline Kangarina wareelacogarra & $\mathbf{x}$ & $\mathbf{x}$ & \\
\hline Oculocytheropteron australopunctatarum & $\mathbf{x}$ & $\mathbf{x}$ & \\
\hline Oculocytheropteron cf. microfornix & $\mathbf{x}$ & $\mathbf{x}$ & \\
\hline Aversovalva spp. & $\mathrm{x}$ & $\mathbf{x}$ & \\
\hline Kuiperiana lindsayi & $\mathrm{X}$ & $\mathrm{x}$ & \\
\hline
\end{tabular}

Table 2. Ostracod species in the Blanche Point Formation recorded from the palaeogene of other regions.

furnished with two rows of tubercles, one row along the commissure and another more proximal row along its lateral edge. There is an anteromarginal depression behind the latter. Posterior margin triangular and spinose along the edge, apex at mid-height. Subcentral tubercle not well defined. Lateral surface covered with tubercles and spines ranging in size from small papillae to very slender spines or more powerfull tubercles with one central pore surrounded by a distal furcation. Lateral ribs are not well defined, although isolated tubercles, or aggregates of small tubercles, tend to define a ventral rib. The isolated tubercles along the dorsal margin are the most powerful, often showing a distal furcation. In juveniles, there is a fine inter-spine reticulation.

Hinge holamphidont, right valve with a stepped anterior tooth, a weakly locellate median groove and a smooth kidney-shaped posterior tooth; left valve complementary. Inner lamellae moderately broad with well defined selvages. Marginal pore canals numerous, straight to sinuous.

Dimensions ( $\mathrm{mm}$ ): The $\mathrm{LV}$ of females ranges in $\mathrm{L}$ from $0.77-0.81$ and in $\mathrm{H}$ from $0.35-0.40$, whereas the $\mathrm{LV}$ of males ranges in $\mathrm{L}$ from $0.82-0.90$ and in $\mathrm{H}$ from $0.36-041$. Holotype, DMGUG.Au.45 (LV, female), $\mathrm{L}=0.81, \mathrm{H}=0.40$. Paratype, DMGUG.Au.46 (Carapace, male), $\mathrm{L}=0.85$ dorsally. Paratype, DMGUG.Au.47 (RV, female), L = 0.80, $\mathrm{H}=0.39$. Paratype, DMGUG.Au.48 (RV, female), $\mathrm{L}=0.78$, $\mathrm{H}=0.38$.

\section{Remarks}

The new species is very similar in shape to the present representatives of $T$. thomsoni Hornibrook, from the Gull Rock Member but considerably smaller and more spinose than the latter. The lateral ornament with its distally furcated spines is similar to the Santonian $T$. raynerae Neale, of Gingin, western Australia; the latter species, however, is considerably larger and has more powerful spines than the new species.

\section{Material}

About 530 specimens from the Gull Rock and the Perkana members.

\section{Trachyleberis reticulopustulosa $\mathrm{sp}$. nov. Pl. II, figs. 5-9}

Derivation of name: From the reticulate and pustulose surface ornament.

Holotype: The male LV specimen DMGUG.Au.50., Pl. II, Fig. 6.

Type locality: The type section of the late Eocene Blanche Point Formation. Holotype from approximately $4.5 \mathrm{~m}$ above the base of the Perkana Member. Paratypes: DMGUG.Au.49, 51-53; Pl. II, Figs. 5, 7-9.

\section{Diagnosis}

A species of Trachyleberis with a valve surface covered with pustules and a fine primary reticulation. Lateral ribs lacking but there are single spines posterodorsally, posteromedianly and postero-ventrally, respectively. Carapace relatively compressed in dorsal view. Sexual dimorphism very prominent.

\section{Description}

Carapace subtriangular to subrectangular in lateral view with the LV being larger than the RV and overlapping it postero- and anterodorsally. Anterior margin semicircular and provided with a rib bearing a double row of denticles. Posterior margin subtriangular and strengthened with a rib 
showing three prominent spines on its ventral section. Carapace depressed behind the anteromarginal rib and in front of the posteromarginal rib. Dorsal margin slightly convex; ventral margin convex. Carapace relatively compressed in dorsal view with the width being about $1 / 3$ of the length. Hinge-ear moderately developed in the LV. Eyetubercles distinct. Subcentral tubercle weakly developed. Valve surface pustulose and with a fine primary reticulation. Lateral ribs completely reduced but there is a spine posterodorsally, posteromedianly and posteroventrally, respectively. Sexual dimorphism prominent; males longer than females.

Hinge holamphidont; the RV with an almost bifid anterior tooth, a smooth median furrow and a large, smooth subtriangular posterior tooth. Inner lamella broad with numerous straight to slightly wavy marginal pore canals.

Dimensions $(\mathrm{mm})$ : The $\mathrm{LV}$ of females ranges in $\mathrm{L}$ from $0.68-0.72$ and in $\mathrm{H}$ from $0.36-0.38$, whereas the $\mathrm{LV}$ of males ranges in $\mathrm{L}$ from $0.72-0-74$ and in $\mathrm{H}$ from $0.34-0.36$. Holotype, DMGUG.Au.50 (LV, male), $\mathrm{L}=0.74, \mathrm{H}=0.36$. Paratype, DMGUG.Au.49 (LV, female), $\mathrm{L}=0.68, \mathrm{H}=0.36$. Paratype, DMGUG.Au.51 (RV, male), $\mathrm{L}=0.72, \mathrm{H}=0.36$. Paratype, DMGUG.Au.52 (Carapace, male), $\mathrm{L}=0.73$ dorsally. Paratype, DMGUG.Au.53 (RV, male), L = 0.73, H $=0.33$.

\section{Remarks}

The new species is similar to Trachyleberis jilletti Ayress, in its lateral shape of the carapace and pustulose ornament, but is considerably smaller and has primary reticulation. The reticulation is somewhat similar to that of Trachyleberis retizea Hornibrook, and Dutoitella hampdenensis Ayress. The latter two species differ from the new species in the lateral outline of the carapace. Otherwise, the ornamentation of the new species is unusual, and distinct in comparison with other Tertiary, Australian and New Zealand species referred to the genus Trachyleberis or allied genera by Hornibrook (1952, 1953), McKenzie et al. (1991, 1993) and Ayress (1993a, 1993b).

\section{Material}

Thirty three specimens sporadically distributed in the Gull Rock and the Perkana Members. Most specimens were single valves representing adults of both sexes and a few juveniles.

Genus Actinocythereis Puri, 1953

\section{Actinocythereis? onkaparingaensis sp. nov. Pl. II, figs. 10-14}

Derivation of name: After the Onkaparinga River which runs to the north of the Willunga Embayment.

Holotype: The female RV specimen DMGUG.Au.56., Pl. II, fig. 12 .

Type locality: The type section of the late Eocene Blanche Point Formation. Holotype from approximately $3.5 \mathrm{~m}$ above the base of the Perkana Member. Paratypes: DMGUG.Au.54-55, 57-58; Pl. II, Figs. 10-11, 13-14.

\section{Diagnosis}

A species tentatively assigned to the genus Actinocythereis, although there are no spines or tubercles on the lateral surface, instead uninterrupted lateral ribs,

\section{Plate II}

1-4 Trachyleberis maslinensis sp. nov. 1. Female LV (holotype). Late Eocene, Perkana Member. DMGUG.Au.45. x 49. $\Delta$ 2. Male carapace dorsal view (paratype). Late Eocene, Perkana Member. DMGUG.Au.46. x 49. $\Delta$ 3. Female RV (paratype). Late Eocene, Perkana Member. DMGUG.Au.47. x 47. $\Delta$ 4. Female RV internal view (paratype). Late Eocene, Perkana Member. DMGUG.Au.48. x 54.

5-9 Trachyleberis reticulopustulosa sp. nov. 5. Female LV (paratype). Late Eocene, Gull Rock Member. DMGUG.Au.49. x 54. $\Delta$ 6. Male LV (holotype): Late Eocene, Perkana Member. DMGUG.Au.50. x 54. $\Delta$ 7. Male RV internal view (paratype). Late Eocene, Gull Rock Member. DMGUG.Au.51. x 54. $\Delta$ 8. Male carapace dorsal view (paratype). Late Eocene, Gull Rock Member. DMGUG.Au.52. x 54. $\Delta$ 9. Male RV (paratype). Late Eocene, Gull Rock Member. DMGUG.Au.53. x 54.

10-14 Actinocythereis? onkaparingaensis sp. nov. 10. Female carapace dorsal view (paratype). Late Eocene, Gull Rock Member. DMGUG.Au.54. x 60. $\Delta 11$. Female LV (paratype). Late Eocene, Gull Rock Member. DMGUG.Au.55. x 60. $\Delta$ 12. Female RV (holotype). Late Eocene, Gull Rock Member.
DMGUG.Au.56. x 60. $\Delta$ 13. Female RV internal view (paratype). Late Eocene, Gull Rock Member. DMGUG.Au.57. x 60. $\Delta$ 14. Male RV (paratype). Late Eocene, Gull Rock Member. DMGUG.Au.58. x 60.

15 Actinocythereis? sp. LV. Late Eocene, Perkana Member. DMGUG.Au.59. x 40.

16-19 Werribeeleberis? mediacosta sp. nov. 16. LV (holotype). Late Eocene, Gull Rock Member. DMGUG.Au.60. x 60. $\Delta$ 17. RV internal view (paratype). Late Eocene, Gull Rock Member. DMGUG.Au.61. x 60. $\Delta$ 18. RV (paratype). Late Eocene, Gull Rock Member. DMGUG.Au.62. x 69. $\Delta$ 19. Carapace in dorsal view (paratype). Late Eocene, Gull Rock Member. DMGUG.Au.63. x 60.

20-24 Bradleya mypongaensis sp. nov. 20. LV (holotype). Late Eocene, Gull Rock Member. DMGUG.Au.64. x 47. $\Delta$ 21. Carapace in dorsal view (paratype). Late Eocene, Gull Rock Member. DMGUG.Au.65. x 44. $\Delta$ 22. RV (paratype). Late Eocene, Gull Rock Member. DMGUG.Au.66. x 45. $\Delta$ 23. RV internal view (paratype). Late Eocene, Gull Rock Member. DMGUG.Au.67. x 60. $\Delta$ 24. LV closer view of ornamentation (holotype). Late Eocene, Gull Rock Member. DMGUG.Au.64. x 95. 
Plate II

1

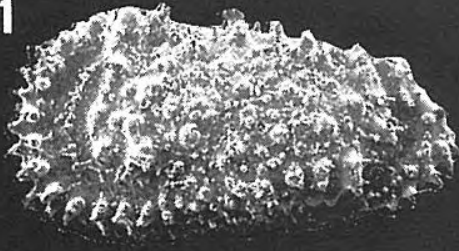

4

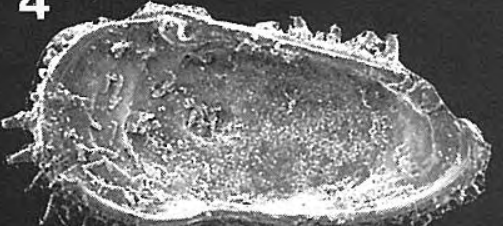

7
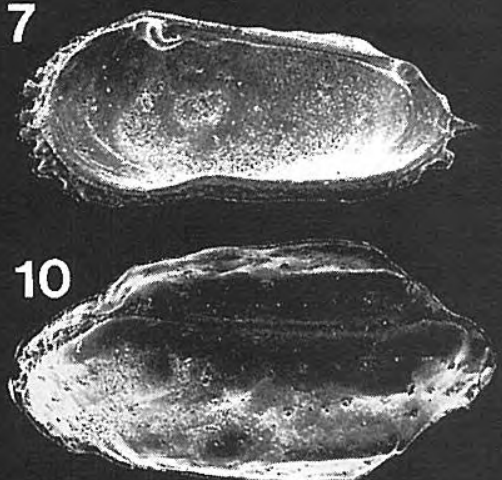

13

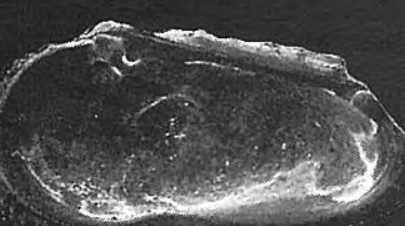

16

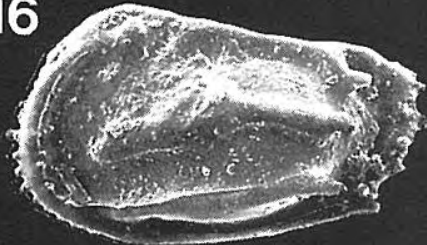

20

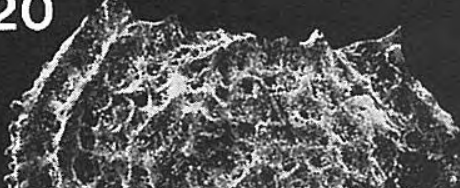
(2), 3 ,

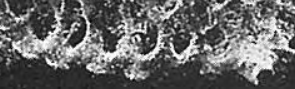

\section{2}

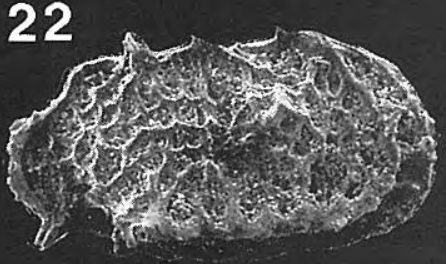

\section{2}

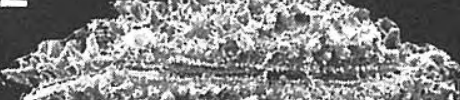

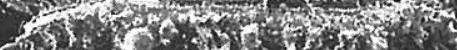

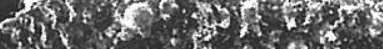
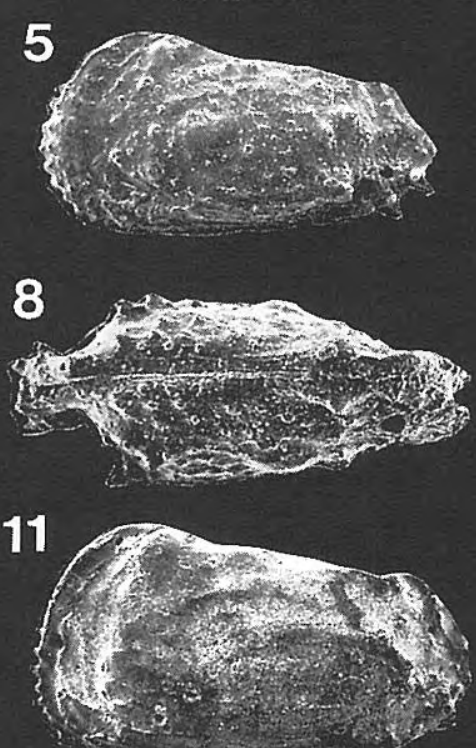

14
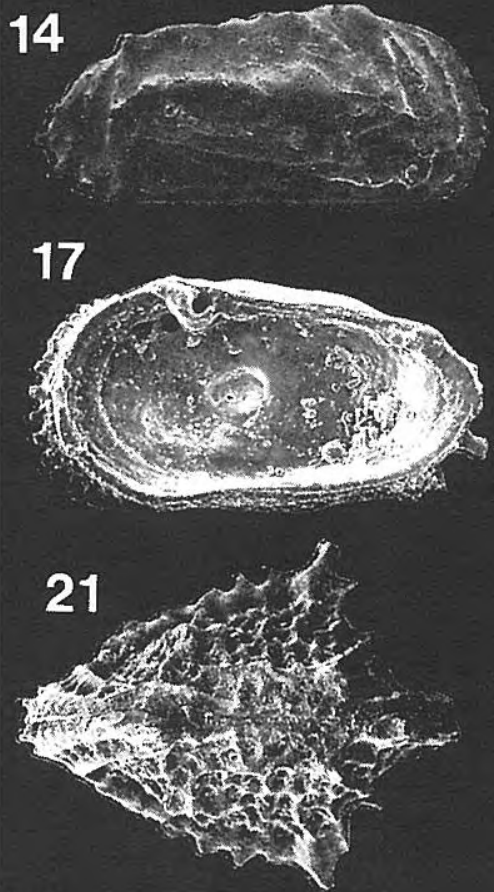

23

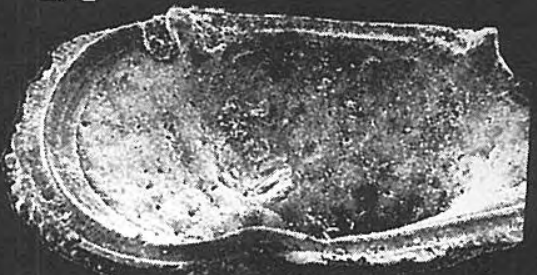

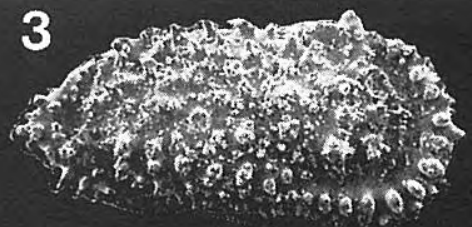

6 is:

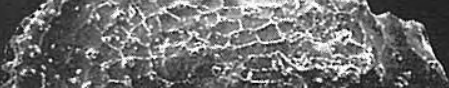

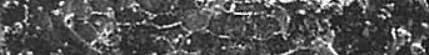
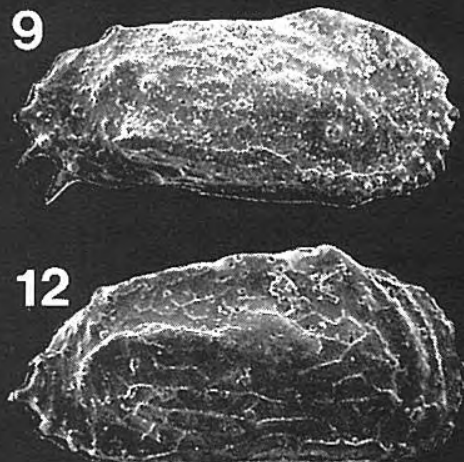

15

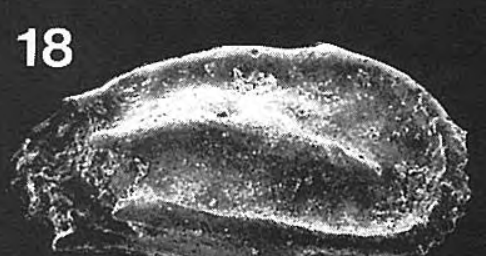

19

\section{4}

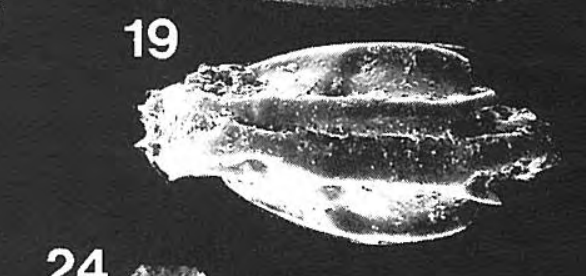

and

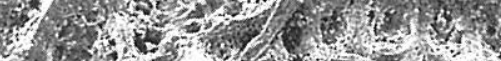

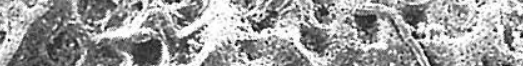

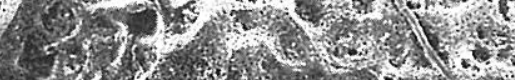

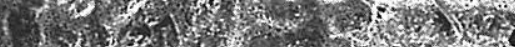

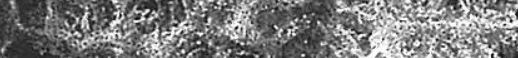

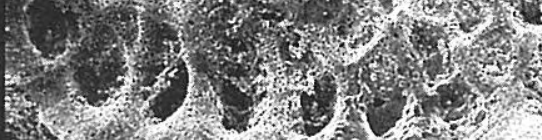
H.2. 
and a primary reticulation which varies in its extension over the valve surface. Two thin anterior ribs runs parallel to the anterior margin.

\section{Description}

Carapace subrectangular in lateral view and fusiform in dorsal view. LV larger than the RV and conspicuously overlapping the latter antero- and posteromarginally. Greatest length slightly below mid-height. Greatest height anterior to the distinct eye-tubercle. Anterior margin almost evenly rounded in the RV, more obliquely so in the LV; it is adorned with denticles along almost its entire length in the RV but only below mid-height in the LV. Two thin anteromarginal ribs run parallel to the anterior margin. Posterior margin triangular and furnished with denticles along the ventral section. Lateral surface with three lateral ribs and a fine primary reticulation which is variable in its extension over the valve surface. Ventral rib very weak and appears integrated with the primary reticulation in lateral view. Median rib entire, uninterrupted and straight, terminating posteriorly in a downwards deflexion. Dorsal rib straight in the LV, more uneven in the RV. Subcentral tubercle prominent but not clearly delimited from the surrounding surface. There is a small inflation of the valve surface slightly below and anterior to the subcentral tubercle. Sexual dimorphism weak with females being somewhat higher than males.

Hinge holamphidont; the RV with a bipartitioned anterior tooth, a smooth or faintly locellate median furrow and a smooth subrectangular posterior tooth. LV hinge complementary. Marginal zone broad. Avestibulate. Marginal pore canals numerous, straight to slightly curved.

Dimensions $(\mathrm{mm})$ : The $\mathrm{LV}$ of females ranges in $\mathrm{L}$ from $0.69-0.74$ and in height from $0.40-0.42$, whereas the LV of males ranges in $\mathrm{L}$ from $0.72-0.74$ and in height from 0.39 0.40. Holotype, DMGUG.Au.56 (RV, female), $\mathrm{L}=0.65, \mathrm{H}=$ 0.36. Paratype, DMGUG.Au.54 (Carapace, female), $\mathrm{L}=0.74$ dorsally. Paratype, DMGUG.Au.55 (LV, female), L=0.73, $\mathrm{H}=0.40$. Paratype, DMGUG.Au.57 (RV, female), $\mathrm{L}=0.67$, $\mathrm{H}=0.32$. Paratype, DMGUG.Au.58 (RV, male), $\mathrm{L}=0.69$, $\mathrm{H}=0.33$.

\section{Remarks}

The assignation to the genus Actinocythereis is tentative. The external reticulation of the present species is most unusual for the spinose genus Actinocythereis but similar to Trachyleberis reticulopustulosa $\mathrm{sp}$. nov. The internal features demonstrate a clear affinity to the genera Trachyleberis and Actinocythereis. The author, in view of this, has refrained from erecting yet another monospecific trachyleberine genus. Actinocythereis scutigera costasta Hartmann, is another representative referred to the genus Actinocythereis without a spiny lateral surface but with entire uninterrupted lateral ribs.

\section{Material}

Thirty six specimens sporadically distributed in the Gull Rock and the Perkana Members, mostly single valves representing both sexes.

\author{
Actinocythereis? sp. \\ Pl. II, fig. 15
}

\section{Description}

LV large and subrectangular in lateral aspect. There are three lateral ribs. Each of the dorsal and median ribs consist of a few powerful, cone-like spines. The spines of the ventral rib are numerous (about 10) and appear somewhat flattened. The ventral rib is continuous with the double-row of small anteromarginal spines along the ventral half of the evenly rounded anterior margin. Posterior margin triangular with small spines along the ventral section. Valve surface smooth, inflated medianly and compressed behind the anterior margin and in front of the posterior margin. The eye-tubercle is very prominent and positioned behind the anterior cardinal angle. The subcentral tubercle is moderate and disrupted. Three cone-like spines are situated slightly anterior to and below the subcentral tubercle. Internal features not clearly seen due to unremovable sediment.

Dimensions (mm): The two LV have a $\mathrm{L}$ of 1.2 and a mean $\mathrm{H}$ of 0.54 .

\section{Remarks}

This species is clearly differentiated from other trachyleberidid species described from the Palaeogene of southern Australia and New Zeland (Hornibrook, 1952, 1953; McKenzie et al., 1991, 1993; Ayress, 1993a, $1993 \mathrm{~b})$. It is tentatively referred to the genus Actinocythereis by reference to the three well defined lateral ribs.

\section{Material}

Three valves ( $2 \mathrm{LV}$ and 1 damaged RV) from the P12 sample of the Perkana Member.

Genus Werribeeleberis McKenzie, Reyment \& Reyment, 1993

\section{Werribeeleberis? mediacosta $\mathrm{sp}$. nov. Pl. II, figs. 16-19}

Derivation of name: Costa (L.) = rib; for the well developed median rib.

Holotype: The LV specimen DMGUG.Au.60., Pl. II, fig. 16.

Type locality: Type section of the late Eocene Blanche Point Formation. Holotype from approximately $1.5 \mathrm{~m}$ above the base of the Gull Rock Member. Paratypes: DMGUG.Au.61-63; Pl. II, Figs. 17-19.

\section{Diagnosis}

A species of Werribeeleberis with a well developed median rib and a small eye-tubercle; the LV overlaps the $\mathrm{RV}$ almost along the entire circumference.

\section{Description}

Carapace inequivalved and subrectangular in lateral view; subhastate in dorsal view. Greatest height at the hinge- 
ear of the LV. LV conspicuously larger than the RV and overlaps it along almost the entire margin. Posterior margin subtruncate with denticles ventrally, the ventral part of the posterior margin is extended far above mid-height in the LV. Anterior margin almost evenly rounded, semicircular in the $\mathrm{RV}$ somewhat more oblique in the $\mathrm{LV}$; it is provided with a prominent rib which is dentate; this anteromarginal rib is continuous with the dorsal and ventral rib, respectively, thus forming an u-shaped loop that surrounds a conspicuously long median rib. The continuity between the anteromarginal rib and the dorsal rib is more distinct in the RV, less so in the LV as the connection runs over the hinge-ear. Each of the three lateral ribs terminates posteriorly in a spine. Valve surface smooth, depressed behind the anteromarginal rib, more inflated medianly and compressed in the posteromarginal region. Subcentral tubercle small and obscured by the median rib. Eye-tubercle small but distinct especially in the LV. Sexual dimorphism not clearly expressed in the present material.

Hinge holamphidont, the RV with a smooth anterior tooth, a smooth median furrow and a smooth subtriangular posterior tooth. Inner lamella moderately broad; numerous marginal pores which are straight to slightly curved; a very narrow vestibule has been observed in the RV (on the best preserved individual). Central muscle-scars with four adductors in a subvertical row and $\mathrm{v}$-shaped frontal scar.

Dimensions ( $\mathrm{mm}$ ): The LV ranges in L from $0.64-0.67$ and in $\mathrm{H}$ from 0.38-0.40. Holotype, DMGUG.Au.60 (LV), $\mathrm{L}=$ $0.64, \mathrm{H}=0.38$. Paratype, DMGUG.Au.61 (RV), $\mathrm{L}=0.61, \mathrm{H}$ $=0.34$. Paratype, DMGUG.Au.62 (RV), L = 0.59, $\mathrm{H}=0.31$. Paratype, DMGUG.Au.63 (Carapace), $\mathrm{L}=0.65$ dorsally.

\section{Remarks}

The morphology of the new species seems to be intermediate between the genera Curfsina Deroo, and Werribeeleberis McKenzie, Reyment \& Reyment. (McKenzie, pers. com.). Curfsina is generally more thick-shelled than the present forms and displays crenulated terminal teeth in the right hinge. The new species is, however, distinguished from the original description of Werribeeleberis (cf. McKenzie et al., 1993) by displaying eye-tubercles and a median rib. Otherwise, the new species is very similar to Werribeeleberis trispinosa, particularly the u-shaped loop formed by the continuity between the anteromarginal, dorsal and ventral ribs and the spiny posterior termination of the longitudinal ribs, features which are highly diagnostic of the latter genus.

\section{Material}

Six adult valves of the Gull Rock Member. Additional large samples from the base of the Gull Rock Member (not included in appendices 1-2) have yielded about forty specimens of this species.

Family Thaerocytheridae Hazel, 1967 Subfamily Bradleyinae Benson, 1972 Genus Bradleya Hornibrook, 1952

\section{Bradleya mypongaensis sp. nov. Pl. II, figs. 20-24}

1993 Bradleya sp. McKenzie, Reyment \& Reyment, 113, pl. VII, fig. 14.

Derivation of name: After the Myponga River which runs to the south of the Willunga Embayment.

Holotype: The LV specimen DMGUG.Au.64., Pl. II, fig. 20.

Type locality: Type section of the late Eocene Blanche Point Formation. Holotype from approximately $1 \mathrm{~m}$ above the base of the Gull Rock Member. Paratypes: DMGUG.Au.65-67; Pl. II, figs. 21-23.

\section{Diagnosis}

A large species of Bradleya ornamented with numerous, small irregular reticules showing a dense microreticulation of the muri. Eye-tubercles absent. A powerful spine positioned at the posteroterminal termination of the dorsal and ventral ribs, respectively; also at the posterior cardinal angle and at the ventral base of the posterior margin, respectively. Dorsal rib irregular flattened and undulose.

\section{Description}

Carapace large, subrectangular to subtrapezoid in lateral view; subhastate in dorsal view. Greatest height at the anterior cardinal angle which shows a flattened elevation which is almost spine-like in the RV. Greatest length at midheight. LV valve overlaps the RV antero- and posterodorsally. Anterior margin evenly rounded in the RV, more oblique in the LV; it is adorned with a double-row of small spines of which the spines of the inner row tend to diminish anterodorsally. Posterior margin subtriangular, rimmed and provided with a powerful spine ventrally. Also, a prominent spine occurs at the posterior cardinal angle of the RV. Ornament with numerous, small irregular reticules covering the main region of the valve. The reticulum muri show a dense microreticulation. Ventral rib very prominent with its posteroterminal termination marked by a powerful spine; it is lined dorsally with six large fossae. The ventral rib is prolonged into an ocular rib which is lined by large fossae on either side. Dorsal rib irregular, undulose, flattened and provided with a vigorous posteroterminal spine. Median rib and subcentral bridge absent. Eyetubercle, nor sexual dimorphism not clearly identified.

Hinge holamphidont with a weakly locellate posteromedian furrow in the RV. Marginal zone moderately wide with a distinct selvage nearer to the outer than to the inner margin. Marginal pore canals numerous, almost straight.

Dimensions (mm): The LV ranges in L from 0.90-0.95 and in $\mathrm{H}$ from 0.50-0.54. Holotype, DMGUG.Au.64 (LV), $\mathrm{L}=$ $0.95, \mathrm{H}=0.54$. Paratype, DMGUG.Au.65 (Carapace), $\mathrm{L}=$ 0.95 dorsally. Paratype, DMGUG.Au.66 (RV), L = 0.89, H $=0.49$. Paratype, DMGUG.Au.67 (RV), L = 0.91, $\mathrm{H}=0.50$. 


\section{Remarks}

The new species seems conspecific with Bradleya sp. of McKenzie et al. (1993) who first recognized the independent status of this taxon. It lacks the rectangular, subcentral bridge which is diagnostic of Bradleya species of the dictyon-group (cf. Whatley et al., 1983). The new taxon is probably most similar to the Eocene, Southwest Pacific Bradleya multireticulata Whatley, Harlow, Downing \& Kaesler, in view of the size and number of the surface reticules and to the Eocene, Southwest Pacific Bradleya labyrinthica Whatley, Harlow, Downing \& Kaesler, in view of the lateral shape (see Whatley et al., 1984). It may be distinguished from the latter two species by, for example, the lack of a clearly identifiable eyetubercle and by reference to the posterior shape.

\section{Material}

Six adult valves at the base of the Gull Rock Member. Additional large samples from the base of the Gull Rock Member (not included in appendices 1-2) have yielded about one hundred specimens of this species including many juveniles.

\section{ACKNOWLEDGEMENTS}

The author wishes to acknowledge Ben McHenry, Ben Grauric and Stephen Holder, for assistance in fieldwork; two anonymous referees for their critical comments which improved this paper; Graham Moss, Adelaide and Amanda Circosta, New Guinea, for providing information on the foraminifers of the Blanche Point Formation; and to Michal Kucera and Bjorn Malmgren, for stimulating discussions during the course of this study. The research was financed by Post Doctoral Grant (G-GU 6656-300) from the Swedish Natural Science Research Council, and with grants from Th Nordströms testamentsfond which were supplied through the Royal Swedish Academy of Sciences.

\section{BIBLIOGRAPHY}

Ayress, M.A. 1990. New cytheromatid Ostracoda from the Cenozoic of New Zealand. New Zealand Natural Sciences, 17, 67-72.

Ayress, M.A. 1993a. Ostracod biostratigraphy and palaeoecology of the Kokoamu Greensand and Otekaike Limestone (Late Oligocene to Early Miocene), North Otago and South Canterbury, New Zealand. Alcheringa, 17, 125-151.

Ayress, M.A. 1993b. Middle Eocene Ostracoda (Crustacea) from the coastal section, Bortonian Stage, at Hampden, South Island, New Zealand. New Zealand Natural Sciences, 20, 15-21.

Boomer, I. and Whatley, R. 1992. Ostracoda and dysaerobia in the Lower Jurassic of Wales: the reconstruction of past oxygen levels. Palaeogeography, Palaeoclimatology, Palaeoecology, 99, 373-379.

Buonaiuto, M.F. 1979. Late Eocene Molluscs and related composite species from southern Australia. Unpub. Ph.D. Thesis. University of Adelaide.
Cooper, B.J. 1977. New and revised stratigraphic nomenclature in the Willunga Embayment. Quarterly geological Notes, Geological Survey of South Australia, Adelaide, 64, 2-5.

Cooper, B.J. 1979. Eocene to Miocene stratigraphy of the Willunga Embayment. Geological Survey of South Australia, Report of Investigations, 50, 1-101.

Corliss, B.H., Martinson, D.G. and Keffer, T. 1986. Late Quaternary deep-ocean circulation. Geological Society of America Bulletin, 97, 1106-1121.

Hornibrook, N. de B. 1952. Tertiary and Recent marine Ostracoda (Crustacea) of New Zealand. Palaeontological Bulletin New Zealand Geological Survey, Wellington, 18, 1-182.

Hornibrook, N. de B. 1953. Some New Zealand Tertiary marine Ostracoda useful in stratigraphy. Transactions of the Royal Society of New Zealand, 81, 303-311.

Hurlbert, S.H. 1971. The nonconcept of species diversity: a critique and alternative parameters. Ecology, 52, 577586.

Jenkins, R.J.F., Jones, J.B., McGowran, B., Beecroft, A.S., and Fitzgerald, M.J. 1982. Lithostratigraphic subdivision of the Blanche Point Formation, Late Eocene, Willunga Embayment. Quarterly geological Notes, Geological Survey of South Australia, Adelaide, 84, 2-7.

Jones, J.B. and Fitzgerald, M.J. 1984. Extensive Volcanism Associated with the Separation of Australia and Antarctica. Science, 226, 346-347.

Jones, J.B. and Fitzgerald, M.J. 1986. Silica-rich layering at Blanche Point, South Australia. Australian Journal of Earth Sciences, 33, 529-551.

Lindsay, J.M. 1967. Foraminifera and stratigraphy of the type section of the Port Willunga Beds, Aldinga Bay, South Australia. Transactions of the Royal Society of South Australia, Adelaide, 91, 93-110.

Lindsay, J.M. 1985. Aspects of South Australian Tertiary foraminiferal biostratigraphy, with emphasis on studies of Massilina and Subbotina. In: Stratigraphy, Palaeontology, Malacology: Papers in honour of Dr. Nell Ludbrook, (Ed. J.M. Lindsay), 187-232. Special Publication, South Australian Department of Mines and Energy No. 5. Adelaide. Geological Survey of South Australia.

McGowran, B. and Beecroft, A. 1986. Foraminiferal biofacies in a silica-rich neritic sediment, South Australia. Palaeogeography, Palaeoclimatology, Palaeoecology, 52, 321-345.

McKenzie, K.G. 1974. Cenozoic Ostracoda of southeastern Australia with the description of Hanaiceratina new genus. Geoscience and Man, 6, 153-182.

McKenzie, K.G. 1979. Appendix 2. Notes on Ostracoda from Willunga Embayment Boreholes WLG 38, WLG 40 and WLG 42. In: Eocene to Miocene Stratigraphy of the Willunga Embayment, (Ed. B. J. Cooper), 90-101. Geological Survey of South Australia, Report of Investigations, Adelaide, $\mathbf{5 0 .}$

McKenzie, K.G. and Guha, D.K. 1987. A comparative analysis of Eocene/Oligocene boundary Ostracoda from southeastern Australia and India with respect to their usefulness as indicators of petroleum potential. 
Transactions of the Royal Society of South Australia,

111, 15-23.

McKenzie, K.G., Reyment, R.A. and Reyment, E.R. 1991. Eocene-Oligocene Ostracoda from South Australia and Victoria, Australia. Revista Española de Paleontología, 6, 135-175.

McKenzie, K.G., Reyment, R.A. and Reyment, E.R. 1993. Eocene Ostracoda from the Browns Creek Clay and Castle Cove, Victoria, Australia. Revista Española de Paleontología, 8, 75-116.

Reynolds, M.A. 1953. The Cainozoic succession of Maslin and Aldinga Bays. Transactions of the Royal Society of South Australia, 76, 114-140.
Swanson, K.M. 1979. The Marine Fauna of New Zealand: Ostracods of the Otago Shelf. New Zealand Oceanographic Institute Memoir, 78, 1-56.

Warne, M.T. 1988. Neonesidea and Bairdoppilata (Ostracoda) from the Miocene of the Port Phillip and Western Port Basins, Victoria, Australia. Alcheringa, 12, 7-26.

Whatley, R. 1988. Population structure of ostracods: some general principles for the recognition of palaeoenvironments. In: Ostracoda in the Earth-Sciences, (Eds. P. De Deckker, J.-P. Colin and J.-P. Peypouquet), 245-256. Elsevier.

Whatley, R. 1991. The platycopid signal: a means of

Appendix 1. Ostracod species and number of specimens in the Gull Rock Member.

\begin{tabular}{|c|c|c|c|c|c|c|c|c|c|c|c|}
\hline Sample: & $6 \mathrm{~B}$ & $8 B$ & $10 \mathrm{~B}$ & $\mathrm{G} 25$ & G22 & G19 & G16 & G13 & G9 & G7 & G3 \\
\hline Cytherella gullrockensis & 164 & 131 & 174 & 35 & 25 & 9 & 6 & 24 & 33 & 43 & 39 \\
\hline Cytherella sp. & & & & & & & & & & 1 & 2 \\
\hline Cytherelloidea jugifera & 1 & 6 & 7 & 3 & 5 & 11 & 17 & 13 & 13 & 28 & 18 \\
\hline Cytherelloidea marginopytta? & & 2 & & & & & & 1 & & & \\
\hline Bairdoppilata willungaensis sp. nov. & 15 & 60 & 8 & 9 & & 10 & 2 & & & & 1 \\
\hline Neonesidea sp. & & & & 4 & 4 & 1 & 1 & & & & 2 \\
\hline Bythocypris sudaustralis & & & $1 ?$ & 31 & 15 & 26 & 9 & 5 & 7 & 25 & 12 \\
\hline Macrocypris sp. & & & & & & & 1 & & & & \\
\hline Tasmanocypris? sp. & 2 & & & & & & & & & 2 & \\
\hline Paracypris aff. bradyi & & & & 13 & 6 & 3 & 8 & 5 & 3 & 4 & 5 \\
\hline Argilloecia spp. (juv.) & 5 & 3 & 11 & 13 & 25 & 26 & 22 & 14 & 19 & 38 & 14 \\
\hline Maddocksella tarparriensis & 4 & 6 & 16 & 24 & 13 & 6 & 19 & 14 & 7 & 5 & 9 \\
\hline Hornibrookella sp. 1 & 1 & & & & & & & & & & \\
\hline Trachyleberis thomsoni & 31 & 25 & 5 & 43 & 24 & 10 & 10 & & & & \\
\hline Trachyleberis maslinensis sp. nov. & cf.6 & cf. 2 & & & & & & $3 ?$ & $1 ?$ & 8 & 44 \\
\hline Trachyleberis reticulopustulosa sp. nov. & 1 & 1 & 1 & & & & 1 & & & & 3 \\
\hline Trachyleberis paucispinosa & & & & 1 & & & & & & & \\
\hline Actinocythereis? onkaparingaensis sp. nov. & 1 & 1 & & & & 1 & 1 & & & & \\
\hline Werribeeleberis? mediacosta $\mathrm{sp}$. nov. & & 5 & & & & & & & & & \\
\hline Deltaleberis delicata? & 3 & 1 & 2 & 1 & & & & & & & \\
\hline Anebocythereis hostizea? & & 3 & 5 & & & & & & & & \\
\hline Echinoythereis karooma & 7 & 2 & 5 & 4 & 4 & 3 & 2 & 4 & & & 48 \\
\hline Clethocythereis sp. & 3 & 8 & & & & 1 & & & & & \\
\hline Clethocythereis taroona & 8 & 4 & 1 & & & & 2 & 4 & & 2 & \\
\hline Quasibradleya cf. momitea & & & & 6 & 4 & & & & & 4 & 16 \\
\hline Bradleya mypongaensis sp. nov. & 5 & & $1 ?$ & & & & & & & & \\
\hline Cytheralison $\mathrm{sp}$. & & $1 ?$ & & $1 ?$ & & & & & & & \\
\hline Krithe postcircularis & 4 & 4 & 13 & & 41 & 35 & 39 & 36 & 26 & 45 & 48 \\
\hline Cluthia? sp. & 1 & & & $2 ?$ & & & & & & & \\
\hline Eucythere parapubera? & 1 & & 1 & & & & 1 & 4 & & & 3 \\
\hline Eucythere pseudsubovalis? & 1 & & & & & & & & & & \\
\hline Arcacythere sp. & 2 & & & & & & & & & & \\
\hline Arcacythere eocenica & 1 & & & & & & & & & & \\
\hline Munseyella dunoona & & 4 & 1 & 2 & & & 3 & 6 & 4 & & \\
\hline Hemicytherura? sp. & & 1 & & & & & & & & & \\
\hline Kangarina wareelacogarra & 7 & 1 & 5 & 6 & 1 & 1 & 8 & 2 & 2 & 1 & 2 \\
\hline Eucytherura cameloides? & 3 & 3 & 1 & & & & 1 & & & & \\
\hline Eucytherura sp. & & & & & & & 1 & & & & \\
\hline Semicytherura sp.1 & 1 & & & & & & & & & & \\
\hline Semicytherura sp. 2 & 2 & 4 & & $2 ?$ & & 1 & & & & & \\
\hline Semicytherura costulopunctata & & & 1 & & & & 1 & & 1 & & \\
\hline Oculocytheropteron australopunctatarum & 1 & 1 & 2 & 6 & 3 & 3 & 11 & 7 & 3 & 8 & 39 \\
\hline Oculocytheropteron cf. microfornix & 2 & 9 & 1 & 9 & 10 & 16 & 8 & 2 & & 4 & \\
\hline Cytheropteron $\mathrm{sp}(\mathrm{p})$ & 2 & & 3 & 2 & & & 3 & & & & \\
\hline Aversovalva spp. & 9 & 3 & 3 & 4 & & 2 & 11 & 2 & 1 & 1 & 6 \\
\hline Xestoleberis $\mathrm{sp} .1$ & 1 & 4 & 1 & 1 & 4 & 1 & 1 & & & & 4 \\
\hline Xestoleberis $\mathrm{sp} .2$ & 1 & 1 & 3 & & & & & & & & \\
\hline Xestoleberis $\mathrm{sp} .3$ & & & & 2 & & & & & & & \\
\hline Xestoleberis $\mathrm{sp} .4$ & & & & & & & 4 & & & & \\
\hline Uroleberis $\mathrm{sp}$. & & & 2 & & & & & 1 & & & \\
\hline Kuiperiana lindsayi & 6 & 6 & 6 & 12 & 20 & 21 & 16 & 12 & 8 & 14 & 6 \\
\hline Saida sp. & 2 & 1 & 1 & 1 & & & 2 & & 1 & 1 & 3 \\
\hline Incertae sedis sp. $1(72,84)$ & 1 & & & & & & & & & & \\
\hline Incertae sedis spp. $(60, \ldots)$ & 1 & & & & & 1 & & & 1 & & 1 \\
\hline Total number of specimens: & 306 & 303 & 281 & 237 & 204 & 188 & 211 & 159 & 130 & 234 & 325 \\
\hline Number of taxa distinguished: & 36 & 30 & 28 & 26 & 16 & 21 & 29 & 19 & 16 & 18 & 22 \\
\hline Expected no of species E[100]: & 22 & 20 & 18 & 21 & 15 & 17 & 23 & 18 & 15 & 14 & 18 \\
\hline
\end{tabular}


detecting kenoxic events using Ostracoda. Journal of micropalaeontology, 10, 181-185.

Whatley, R.C., Harlow, C.J., Downing, S.E. and Kesler, K.J. 1983. Observations on the origin, evolution and ecology of the genera Poseidonamicus Benson, and Bradleya Hornibrook. In: Applications of Ostracoda (Proceedings of the eighth international symposium on Ostracoda), (Ed. R.F. Maddocks), 492-509. Houston, Texas: University of Houston, Geosciences.

Whatley, R.C., Harlow, C.J.,Downing, S.E. and Kesler, K.J. 1984. New species of the ostracod genus Bradleya from the Tertiary and Quaternary of DSDP Sites in the Southwest Pacific. Revista Española de Micropaleontología, 16, 265-298.

Whatley, R.C. and Millson, K.J. 1992. Marwickcythereis, a new ostracod genus from the Tertiary of New Zealand. New Zealand Natural Sciences, 19, 41-44.

Whatley, R., Millson, K. and Ayress, M. 1992. Philoneptunus, a new ostracod genus from the Cainozoic of Australasia. Revista Española de Micropaleontología, 24, 43-62.
Manuscrito recibido: 20 de octubre, 1994 Manuscrito aceptado: 29 de mayo, 1995

Appendix 2. Ostracod species and number of specimens in the Perkana Member.

\begin{tabular}{|c|c|c|c|c|c|c|c|c|c|c|}
\hline Sample: & $\mathrm{P} 1$ & P5 & P8 & $\mathrm{P} 12$ & $\mathrm{P} 15$ & $\mathrm{P} 18$ & $\mathrm{P} 21$ & $\mathrm{P} 25$ & P29 & P33 \\
\hline Cytherella gullrockensis & 35 & 24 & 19 & 83 & 73 & 57 & 27 & 103 & 99 & 2 \\
\hline Cytherella sp. & & & & & 1 & 5 & 8 & 4 & 2 & 5 \\
\hline Cytherellidae jugifera & 9 & 3 & 9 & 1 & & & & & & \\
\hline Bairdoppilata willungaensis sp. nov. & & 1 & 2 & 2 & 1 & & 12 & 1 & 11 & 1 \\
\hline Neonesidea $\mathrm{sp}$. & & & & & & & & & & 3 \\
\hline Bairdid sp. & & 1 & & & & & & & & \\
\hline Bythocypris sudaustralis & 20 & 8 & 6 & 6 & 14 & 16 & 25 & 16 & 10 & 13 \\
\hline Bythocypris sp. & & & & & & & 6 & & 1 & 1 \\
\hline Tasmanocypris? sp. & 4 & & 9 & 9 & 1 & 4 & 10 & 3 & 7 & 6 \\
\hline Paracypris aff. bradyi & 3 & 5 & 2 & 2 & 5 & 14 & 6 & 12 & 5 & 10 \\
\hline Argilloecia spp. (juv.) & 7 & 26 & 35 & 25 & 37 & 30 & 43 & 27 & 31 & 37 \\
\hline Maddocksella tarparriensis & 10 & 5 & 14 & 8 & 1 & 8 & 10 & 10 & 1 & 16 \\
\hline Australoecia? sp. & & & & & & & & & & 6 \\
\hline Macrocypris? sp. & & & & & & & 2 & 5 & & \\
\hline \multicolumn{11}{|l|}{ Trachyleberis thomsoni } \\
\hline Trachyleberis maslinensis sp. nov. & 40 & 30 & 41 & 76 & 50 & 45 & 18 & 72 & 70 & 28 \\
\hline Trachyleberis reticulopustulosa sp. nov. & 13 & & & & 3 & 4 & & 2 & 2 & 2 \\
\hline Dutoitella cf. probesioides & & & & & 8 & 12 & & & 1 & \\
\hline Actinocythereis? onkaparingaensis sp. nov. & & & & & 5 & & & & 27 & \\
\hline Actinocythereis? sp. & & & & 3 & & & & & & \\
\hline Deltaleberis delicata? & & & & 3 & & 1 & & 1 & & \\
\hline Echinoythereis karooma & 53 & 16 & 19 & 58 & 30 & & & & & \\
\hline Cletocythereis $\mathrm{sp}$. & & & 2 & 5 & & & & & & \\
\hline Cletocythereis taroona & 2 & 2 & 1 & 1 & & & & 3 & & \\
\hline Quasibradleya cf. momitea & 2 & 5 & 26 & 3 & & 1 & & & & \\
\hline Hermanites? sp. juv. & 1 & & & & & & & & & \\
\hline Cytheralison $\mathrm{sp}$. & & & & & $1 ?$ & & & & & \\
\hline Vitjasiella $\mathrm{sp}$. & & & & & & & & & & 1 \\
\hline Krithe postcircularis & 30 & 29 & 16 & 19 & 7 & 35 & 42 & 50 & 31 & 21 \\
\hline Eucythere parapubera? & 2 & & 1 & 1 & 1 & 7 & & 1 & 1 & 1 \\
\hline Eucythere pseudsubovalis? & 1 & & & & & 1 & & & & \\
\hline Eucythere sp. & & & & & & & & & & 5 \\
\hline Arcacythere sp. & & & & & 1 & 1 & & 1 & 3 & 1 \\
\hline Munseyella dunoona & & & 1 & 2 & 5 & 5 & 2 & 1 & 3 & 6 \\
\hline Munseyella pytta & & & & & & & & & 8 & 4 \\
\hline Kangarina wareelacogarra? & & & & & 1 & 2 & & & 4 & 3 \\
\hline Eucytherura sp. & & & & & & & & & & 1 \\
\hline Oculocytheropteron australopunctatatarum & 30 & 20 & 16 & 6 & 28 & 18 & 4 & 10 & 9 & 3 \\
\hline Oculocytheropteron cf. microfornix & & $1 ?$ & 1 & & $1 ?$ & 1 & & $1 ?$ & 3 & 18 \\
\hline Oculocytheropteron sp. & & & & 1 & & & & & & 1 \\
\hline Aversovalva spp. & & 11 & 20 & 8 & 7 & 7 & 10 & 13 & 12 & 5 \\
\hline Xestoleberis sp. 1 & & & 1 & 5 & 8 & & 3 & & 7 & 6 \\
\hline Xestoleberis sp. 2 & & & & & 1 & & & & & \\
\hline Xestoleberis "araios" & & & & & 1 & & & & & \\
\hline Uroleberis sp. & 1 & & & & & & & & & \\
\hline Kuiperiana lindsayi & 17 & 20 & 7 & 7 & & 6 & & 1 & 1 & 24 \\
\hline Amphicytherura sp. & & & & & & & & & & 1 \\
\hline Saida sp. & & 1 & & 4 & 2 & 1 & & 2 & & \\
\hline Unidentified sp. 1 & & & & & & & 1 & & $2 ?$ & \\
\hline Unidentified sp. 2 & & & & & & & 1 & & & \\
\hline Unidentified sp. 3 & 1 & & & & & & & & & \\
\hline Unidentified sp. 4 & & & 2 & & & & & & & \\
\hline Unidentified sp. 5 & & & & & 1 & & & & & \\
\hline Total number of specimens: & 281 & 208 & 250 & 338 & 294 & 281 & 230 & 339 & 351 & 231 \\
\hline Number of taxa distinguished: & 20 & 18 & 22 & 24 & 27 & 23 & 18 & 22 & 25 & 29 \\
\hline Expected no of species $\mathrm{E}[100]$ : & 16 & 15 & 17 & 18 & 18 & 18 & 16 & 15 & 17 & 23 \\
\hline
\end{tabular}

